\author{
THE SELF-CONTAINED GOVERNOR IN TEKE (ANTALYA) OF MUSTAFA \\ HILMI (URAN) BEY FROM BODRUM (from October 29, 1921 to July \\ $22,1923)$
}

\title{
Muhammet GÜçLÜ**
}

Geliş Tarihi/Received:09.04.2019

Kabul Tarihi/Accepted:11.06.2019

GÜÇடÜ, Muhammet, (2019), “Bodrumlu Mustafa Hilmi (Uran) Bey'in Teke (Antalya) Müstakil Mutasarrıfı̆̆ı (29 Ekim 192122 Temmuz 1923)", Belgi Dergisi, C.2, S.18, Pamukkale Üniversitesi Atatürk İlkeleri ve İnkılâp Tarihi Araştırma ve Uygulama Merkezi Yayını, Yaz 2019/II, ss. 1359-1378.

Öz

Bodrumlu olan Mustafa Hilmi Bey, 1908 yılında Mülkiye Mektebi'nden mezun oldu. Menemen ve Çeşme kaymakamlığı yaptiktan sonra Mülkiye Müfettişi olarak çalıșt. Son Osmanlı Mebusan Meclisi'nde Muğla Mebusu olarak bulundu. Daha sonra bir buçuk yıl kadar Milas'ta serbest çalışt.

Antalya üzerinden Ankara'ya giden Hilmi Bey, orayı "sembolik bir merkez" olarak nitelemektedir. Mutasarrıf olarak Antalya'ya geldiğinde burayı Akdeniz'de hayli zamandan beri işgal dışında olan büyük ve önemli bir limanımız olarak görür. O Antalya Müstakil Mutasarrıflı̆̆ görevini 29 Ekim 1921-22 Temmuz 1923 tarihleri arasında yaptr. Görevinin ilk yılını cephe hazırlıkları ve sağlık işleriyle uğraşarak geçirdi. 9 Eylül 1922 sonrasında ise Rum muhacereti ve şehrin içme suyu sorunuyla meşgul oldu. 1923 yılında ise ikinci dönem Mebus seçimiyle ilgilendi. Seçim sonrasında terfi olarak Adana Valiliği'ne atandı.

Anahtar Kelimeler: Mustafa Hilmi Uran, Bodrum, Antalya, Milli Mücadele, Mebus seçimi

\begin{abstract}
Mustafa Hilmi Bey, from Bodrum, gratuated from Mülkiye Academy in 1908. After he had made district governership in Menemen and Çeşme, he worked as a civil inspector. He placed as a member of parliament in Muğla in the last Ottoman Assembly of Deputies. Afterwards, he worked as a freelance in Milas during a year and half.

Having passed through Antalya, Hilmi Bey, went to Ankara, described there as "the symbolic center". When he had come to Antalya as governer, he saw there as our big and important harbor which hadn't been occupied for a long time. He made the self-contained governership from October 29, 1921 to July 22, 1923. During the early years of his duty, he made the preparations of front and sanitarians things. After September 9, 1922 he was interested in the migration of Greek and the problem of drinking water system. In 1923, he took care of the election of member of parliament in the second period. After the election, he was assigned to the governership of Adana, as rank.
\end{abstract}

Keywords: Mustafa Hilmi Uran, Bodrum, Antalya, National Struggle, Parliamentary Election

\footnotetext{
*Bu makale 4. Uluslararası Her Yönüyle Bodrum Sempozyumu'nda sunulan bildirinin geliştirilmiş şeklidir.

**Dr. Öğretim Üyesi, Akdeniz Üniversitesi Edebiyat Fakültesi Tarih Bölümü, Kampus/Antalya/TÜRKiYE mguclu@ akdeniz.edu.tr, (orcid.org /0000-0001-5590-8743)
} 


\section{Giriş: Mustafa Hilmi (Uran) Bey'in Hayatı}

Bodrum'un yerli ailelerinden (Babası İbrahim Edhem, Annesi Nefise Hanım) birine mensup olan Hilmi Bey, H. 1304/1886-1887 yılında Eskiçeşme mahallesinde doğdu. illk tahsilini kısmen Bodrum kısmen de Liva muhasebecisi olan dedesi İsmail Hakkı Bey'in görev yeri Sakız'da yaptı. Rüştiye tahsilini ise Mal Müdürü olan babasının görev yerleri olan Fethiye ile Demirci'de tamamladı. Günümüzde Atatürk Lisesi olarak bilinen İzmir İdadisi'ne 1900 yılında yatılı olarak kayıt oldu. Burada beş yıl okuduktan sonra 1905 yılında girdiği müsabaka imtihanını kazanarak Mülkiye-i Şahane'ye yazıldı. Öğrenimi sırasında Fatih semtinde Şekerci Hanı'nda kiraladığı bir odada ilk sene Milaslı Bohor İsrail adında bir Yahudi genci ile diğer iki sene ise Ödemişli Şükrü (Saraçoğlu) Efendi ile kaldı. Üç yıllık Mülkiye Mektebi'nden tarihi bir gün olan 23 Temmuz 1908 tarihinde mezunların mutat hediyesi olan altın saati alarak mezun oldu. Bundan sonra İzmir Vilayeti'nde maiyet memurluğu (1908-1911) yaptı. 1911 yılının sonlarında eski Dahiliye Nazırı Halil Menteşe'nin araya girmesi ile Nezaret Mektupçu Şükrü Bey tarafından Kırkağaç Kaymakamlığı'na atanan Hacı Esat Bey'in yerine Menemen Kaymakamı olarak atandı. Menemen Kaymakamlığı döneminde eksikliği ciddi şekilde duyulan ilçe ile karakollar ve vilayet merkezi arasında telefon bağlantısı sağladı. Ayrıca mahsul için zararlı olan çekirge istilası ile mücadelede önemli bir başarı sağladı. ${ }^{1}$

İttihat ve Terakki Fırkası iktidarının kudretli İzmir Valisi Rahmi (Arslan) Bey'in Çeşme Kaymakamı Hacim Muhittin (Çarıklı) Bey'i yanına alıp, İzmir Polis Müdürü yapması üzerine ${ }^{2}$ Hilmi Bey, 14 Mayıs 1914 tarihinde terfi suretiyle Çeşme Kaymakamlığı'na nakledildi. Görevinin ilk günlerinde Balkan Savaşı sonrasında Anadolu'ya akan Müslüman muhacereti, başta Çeşme olmak üzere Çeşme ve havalisinden adalara Rum muhacereti sonucunu doğurdu. Bu dönemde Kaymakam Hilmi Bey, Müslüman ve Rum muhacereti ile meşgul oldu. I. Dünya Savaşı'nın son yılında 21 Mart 1918 tarihinde yine terfi suretiyle Mülkiye Müfettişliği'ne atandığı için İstanbul'a gitti. ${ }^{3}$ Brest-Litovsk anlaşması ile Rus işgalinden kurtulan Elviye-i Selase'de (Kars, Ardahan, Batum) yapılacak plebisit için Dahiliye Nezareti Müsteşarı Abdülhalik (Renda) Bey başkanlığında oluşturulan komisyonda görev alan dört Mülkiye Müfettişi'nden birisi oldu ve Kars'ta görevlendirildi. Sultan VI. Mehmet Vahidettin'in 15 Ağustos 1918 tarihili beyannamesi ile havali Osmanlı topraklarına katıldı. 14 Eylül 1918 tarihli kararname ile Elviye-i Selase, Batum Vilayeti adıyla Osmanlı idari düzeninde yerini aldı. Ancak 30 Ekim 1918 tarihinde imzalanan Mondros Mütarekesi gereğince Osmanlı yetkilileri Kars'tan geri çekilmek durumunda kaldı. Bu arada Karsılır, Mutasarrıfı Hilmi Bey'inde yardımıyla "Kars islam Şurası" adıyla bir Milli Hükümet kurdular. ${ }^{4}$ Bunun üzerine geri dönen Hilmi Bey, Nezaret'in emri gereği Mülkiye Müfettişi olarak Trabzon'da görev yaptı. Ama Giresun'da teftiş yaparken daha önce Çeşme'de yaşanan Rum muhacereti yüzünden hesap vermek üzere tutuklandı ve İstanbul'a getirildi. Emniyet nezarethanesinde İttihat ve Terakki'nin önde gelenlerinden Sait Halim Paşa, Halil (Menteşe) Bey, Ali Fethi (Okyar) Bey ile kaldı. Bu sırada Ali Fethi Bey'i ziyarete gelen Mustafa Kemal Paşa'yı ilk kez gördü. Daha sonra tutuklu olarak gönderildiği Çeşme'de suçsuz bulundu ve hükümetin Mülkiye Müfettişliği görevine son verme girişimleri sürerken o tekrar Trabzon'a görevinin başına döndü. Son Osmanlı Mebus seçimlerinde halk tarafından 300 imzalı dilekçeyle Muğla Mebus adaylığı açıklandı. Muğla

1 Hilmi Uran, Meşrutiyet, Tek Parti, Çok Parti Hatıralarım (1908-1950), İstanbul, 2008, Yayına Hazırlayan: Cem Çobanlı-Pınar Güven, s. 3-28, 46-56.

2 Turgut Çarıklı, Babam Hacim Muhittin Çarıkı-Bir Kuvay-ı Milliyecinin Yaşam Öyküsü, Yay. Haz. Y. Hakan Erdem, İstanbul, 2005, s. 21.

3 Hilmi Uran, a.g.e. , s. 57-76; Mücellidoğlu Ali Çankaya'ya göre 3. Sınıf Mülkiye Müfettişliği'ne Kasım 1917 tarihinde atanmıştır. Mücellidoğlu Ali Çankaya, Yeni Mülkiye Tarihi ve Mülkiyeliler, C. 3, Ankara, 1968-1969, s. 1174 .

4 Sabri Sürgevil, “Hilmi Uran (1886-1957)”, Osmanlılardan Günümüze Her Yönüyle Uluslararası Bodrum Sempozyumu (24-26 Ekim 2007)-Bildiriler, Haz. Ahmet Özgiray-M. Akif Erdoğru, Bodrum, 2008, s. 707-708. 
Mebusu seçildiği için Meclis-i Mebusan’a katılmak için 13 Şubat 1920 tarihinde Mülkiye Müfettişliği görevinden ayrıldı. ${ }^{5}$

\section{A- Hilmi Bey’in Teke (Antalya) Müstakil Mutasarrıflığı}

\section{1- Antalya'ya Gelmesi ve İlk İzlenimleri}

Hilmi Bey, 1 Şubat-31 Mart 1920 tarihleri arasında faaliyet gösteren son Mebusan Meclisi'nin Padişah iradesiyle feshedilmesi (24 Nisan 1920) üzerine yanında eşi ve henüz küçük olan kızı olduğu halde bir İtalyan şilebinin ambarında önce Rodos'a, orada kiraladığı bir kayık ile Marmaris'e ve kara yolu ile Muğla üzerinden babasının yaşadığı Milas'a gitmiştir. Bundan sonra ailevi sebeplerden dolayı Milas'ta komisyonculuk yapmaya başlamıştır. ${ }^{6}$ Ama İstanbul'un işgali üzerine Hilmi Bey'in aksine bir kısım mebuslar (Celaleddin Arif Bey, Hamdullah Suphi Bey, Mazhar Müfit Bey) ile Aydın Mebusu ve Yeni Gün gazetesi sahibi Yunus Nadi Bey Ankara'nın yolunu tutmuştur. Hatta Yunus Nadi Bey, Geyve İstasyonu'nda karşılaştı̆̆ı Kuva-yı Milliye komutanı Kaymakam Mahmut Bey ile arasında geçen konuşmada ".... Mahmut Bey; istanbul Meclis-i Mebusanı'nın büyük ekseriyeti cılık çıktı. Onlar gelmiyorlar. Biz gidenlerse çok ekalliyette kalacağız" demiştir. ${ }^{7}$ Aynı zamanda son Meclis-i Mebusan'ın Reisi olan Celaleddin Arif Bey, Ankara'ya geldikten sonra 10 Nisan 1920 tarihinde Ankara'ya süratle gelmeleri için mebuslara telgraf çekmiş, millete beyanname ve İstanbul'daki yabancı mümessillere protestonameler yayınlanmıştır. ${ }^{8}$ Hakkari Mebusu Mazhar Müfit Bey (Kansu) ise Fransız vapuru ile Doğu Akdeniz'de sonu belirsiz bir yolculuk yaptıktan sonra Taşucu, Silifke Karaman ve Konya üzerinden zor bir yolculukla Nisan ayının sonunda Ankara'ya ulaşabilmiştir. ${ }^{9}$

Hilmi Bey, Milas'ta bulunduğu sırada Ankara hükümeti tarafından kendisine teklif edilen mülki görevlere (Aydın ve Kars Mutasarrıflı̆ıı) önce sıcak bakmadı. Ama yaklaşık bir buçuk yıl sonra ticari işlerinin kötü gitmesinin de etkisiyle Dahiliye Vekaleti Müsteşarı Hamit Bey'in Ardahan Mutasarrıflı̆̆ı önerisini (Eylül 1921) kabul etmiştir. Milas'taki işlerini tasfiye ettikten sonra Küllük iskelesinden bindiği Sovyet Rusya bandıralı vapur ile önce Antalya'ya ulaştı. Burada Mutasarrıf Fahrettin (Kiper) Bey ve Liva büyük memurlarıyla arkadaş gibi hasbihal ederken bir süre sonra oraya Mutasarrıf olacağını hiç düşünmemişti. ${ }^{10}$ Muhtemelen Çeşme Kaymakamlığı zamanından beri tanıdığı İttihat ve Terakki Fırkası'nın İzmir'de yayınlanan gazetesini (Anadolu) yöneten ve şimdi gazeteyi Antalya'da, Antalya'da Anadolu adıyla yayınlayan Haydar Rüştü Bey, Hilmi Bey'in şehre gelişini okuyucularına duyurmakta ve "Muğla Mebus-u sabıkı Mülkiye Müfettişlerinden Hilmi Bey Ardahan Mutasarrıflı̆ı̆'na tayin olunmuş ve mahal-i memuriyetine azimet etmek üzere buraya gelmişdir. Hilmi Bey muktedir, zeki ve faal idare memurlarımızdan olmağla beyan-ı hoş amedi eder ve memuriyet-i cedidelerinde muvaffak olmalarını temenni eyleriz" demekteydi. ${ }^{11}$

Hilmi Bey, o zamanın uzun yol vasıtası olan bir yaylı araba ile Antalya'dan hareket etti ve Burdur, Eğirdir, Gelendos, Akşehir, Konya, Kadınhan, Polatlı üzerinden Ankara'ya ulaştı. ilk defa gördüğü Ankara'yı "sembolik bir merkez" olarak nitelemekte ve devrin kıyafetini "başta kalpak, ayakta külot (pantolon) ve dolak (tozluk)" olarak tarif etmektedir. Hilmi Bey Ardahan'a gitmek için hazırlanırken, Müsteşar Hamit Bey kararın değiştiğini, Teke (Antalya) Müstakil Mutasarrıflığı'na gönderileceğini söylemiştir. Atama işlemini kısa

5 Hilmi Uran, a.g.e. , s. 105-113.

6 Hilmi Uran, a.g.e. , s. 116-127.

7 Yunus Nadi, Ankara'nın Ilk Günleri, İstanbul, 1955, Sel Yayınları, s. 64.

8 Yunus Nadi, Birinci Büyük Millet Meclisi'nin Açılışı ve Issyanlar, İstanbul, 1955, Sel Yayınları, s. 25.

9 Mazhar Müfit Kansu, Erzurum'dan Ölümüne Kadar Atatürk'le Beraber, C. II, Ankara, 1998, 3. bs. , TTK Basımevi, s. $557-565$

10 Hilmi Uran, a.g.e. , s. $127-129,136$.

11 Antalya'da Anadolu, 15 Eylül 1337. 
zamanda tamamladılar ve harcırahını da daha koyu renkli olan Rus altını olarak verdiler. Teke Mutasarrıfı Hilmi Bey, kiraladığı bir yaylı araba ile Cihanbeyli üzerinden Konya'ya ulaştı. Konya'dan sonra geldiği yol güzergâhını takip ederek 29 Ekim 1921 tarihinde Antalya'ya geldi. ${ }^{12}$

Kendisinden önce Teke Mutasarrıfı olan Fahrettin Bey, Fransız işgalinden kurtarılan Mersin'e tayin olduğu için Mutasarrıflığa Kadı Mansur Efendi vekâlet etmekteydi. Hilmi Bey Antalya'ya gelişinin ertesi günü sabahı Kadı Efendi'den Mutasarrıflık görevini devraldı. Yeni Mutasarrıf Hilmi Bey, İzmir henüz Yunan işgali altındaydı dedikten sonra "Antalya hayli zamandan beri Akdeniz'de, işgal dışında olarak, elimizde bulunan büyük ve mühim bir limanımızdı. Gerçi italyanlar bu havaliye kendi malları gözüyle bakıyorlardı. Fakat anlaşılıyor ki, onlar bu iddialarını mülkümüzün son taksimi ve paylaşılması sırasında ileri sürmek kararındaydılar. Şimdiki halde sadece buralara Yunanlıların ayak basmamasına dikkat ediyorlar, her hareketlerinde bize hoş görünmeye çalışarak, bizi incitmekten çekiniyorlardı. Antalya'da bir konsolosları, bir de telsiz tesisleri vardı" diyerek Antalya limanının konumuna ve İtalyanların şehirdeki durumuna dikkat çekiyordu. Bu dönemde Teke Mutasarrıflı̆ıı'nın Antalya, Alaiye, Akseki, Manavgat, Korkuteli, Elmalı, Finike ve Kaş adlarında sekiz kazası olup, geliri daha ziyade hububata dayanıyordu. Bölgede yetişen narenciyenin ticari özelliği olmadığı gibi pamuk ve pirinç ekimi de henüz yaygın değildi. Kasabanın içinden ve kenarından geçen kanallarla sulanan ve bol miktarda yetiştirilen sebzeler de dışarıya sevk edilemiyordu. Sadece mahalli olarak bolluk ve ucuzluk yaratıyordu. Ormanlar ise gelişigüzel kesilerek özellikle Suriye ve Filistin ile kereste ticareti yapılıyordu. Milli Mücadele dönemi olduğu için deniz yolu ile ulaşım güvenli bulunmadığı için kazalar arasında bile hep kara araçlarıyla ulaşım sağlanıyordu. Hilmi Bey, Antalya halkının durumunu "...Ferdi ve ictimai bütün kuvvet, milli kurtuluş savaşına vakfedilmiş olduğundan onun dışında her şeyde bir durgunluk ve ümitle bekleme havası hakim bulunuyordu. Büyük dava, Milli Mücadele'yi zaferle sona erdirebilmekti. Bu dava yolunda herkes hassastı, herkes uyanıktı ve her faaliyet, bu davanın yürüyüş temposuna zarar vermeme esasına göre ayarlanıyordu..." diye tarif etmekteydi. ${ }^{13}$ Göreve başlamasının ikinci günü yani 31 Ekim 1921 tarihinde İbradı Nahiye Müdürü Macit Efendi'ye (Selekler) yazdığı yazıda "Memuriyeti asliyemiz olan Melli Nahiyesi Müdüriyeti'ne iadeniz tensip kılındığından hemen mahalli memuriyetinize azimetle işe mübaşeretinizin ve selefinizin infikaki tarihlerinin işarı beyan olunur" demekteydi. ${ }^{14}$ Burada adı geçen Macit Efendi ise gelecekte ünlü bir hukukçu ve şair olan Hamit Macit Bey ${ }^{15}$ ile Demokrat Parti Antalya Mebusu Avukat Adnan Selekler'in babası idi. ${ }^{16}$ Macit Efendi iki aylık geçici görev yeri olan İbradı'dan asıl görev yeri olan Melli'ye giderken Mutasarrıf Hilmi Bey'i ziyaret etmiş, İbradı'ya ilişkin hazırladığı raporunu takdim etmiştir. Mutasarrıf raporu beğenmiş olacak ki Macit Efendi kendisini bir ziyaretinde takdir ve iltifatına mazhar olduğunu belirtmektedir. Melli'den sonra Serik nahiye müdürlüğü yapan Macit Efendi, 21 Aralık 1923 tarihli Serik raporunda Mutasarrıf Hilmi Bey ile Jandarma Kumandanı Osman Nuri (Sarol) Paşa'nın Çakallık yolundan nahiyeyi ziyaret ettiklerini yazmaktadır. Nahiye müdürü dönüş sırasında kılavuz jandarmaya Mutasarrıfı şose güzergâhından Çiftçi Alanı, Kayaburnu, Karakaş Çiftliği ve Hamzabalı menfezlerinden Antalya'ya götürmesini tembih etti. Amaç yolun durumunu Mutasarrıfa göstermek ve $20 \mathrm{~km}$ mesafede eksik menfezleri göstermek idi. Bir hafta sonra Hilmi Bey, Macit Bey'i tahmin ettiği üzere Antalya'ya çağırmış, seni mutemet yapsak köprüler için gerekli keresteyi kestirebilir misin demiş. Hususi Muhasebe'den Nahiye Meclis azası Feyzi Efendi adına mutemet olarak 500 lira alan Macit Bey, Büğüş

12 Hilmi Uran, a.g.e. , s. 129-136; Mücellidoğlu Ali Çankaya'ya göre 11 Kasım 1921-3 Ağustos 1923 tarihleri arasında Müstakil Teke Mutasarrıfi olarak görev yapt. Mücellidoğlu Ali Çankaya, a.g.e. , s. 1175.

13 Hilmi Uran, a.g.e. , 136-138.

14 Macit Selekler, Yarımasrın Arkasından-Antalya'da Kemer Melli-ibradı Serik, İstanbul, 1960, s 44.

15 Behçet Necatigil, Edebiyatımızda Isimler Sözlüğü, 10. bs. , İstanbul, 1980, s. 313.

16 Demokrat Parti Milletvekilleri Albümü 1946-1960, Haz. Güner Sarısözen, Demokratlar Kulübü Yayınları No.

17, Ankara, 1998, s. 53. 
köyü ormanlarından jandarma eşliğinde kereste kestirdi. Böylece Hamzabalı ve Çiftçi Alanı menfezlerinin yapımı Mühendis Şemoel Kemal'e ihale edildi. Mutasarrıflığın emri üzerine Cumalı-Kayaburnu arasındaki şose yol vergisi borcu olanlara yaptırıldı. Baba Burnu, Gazeller tarafında eskiden kırılan taşları ise Çiftçi Alanı'ndaki yola naklettirerek yolun kış-yaz işlemesi sağladı. Böylece Hilmi Bey Aksu-Serik arasında şosenin işlemesine önemli bir katkı yapmış oldu. ${ }^{17}$

Teke Mutasarrıfı Hilmi Bey gibi Bodrumlu olan Tabakoğlu Süleyman Nuri Efendi (Öz), İzmir Dar'ül Muallimi'nde birinci sınıf olmadığı için dördüncü sınıfların içinde bir süre okudu ve öğretmenlerinin Milli Kütüphane İdare Kurulu'ndan sağladığı yol parası ile 1921 yılının Ocak ayında İtalyan bandıralı Tirol vapuru ile tahsilini sürdürmek için Antalya'ya (Darülmuallimin) ${ }^{18}$ geldi. Şehir ve kendi durumu hakkında şöyle demektedir: "Bir kış baharında, Akdeniz'in iki mavi ufuk arasında, yeşillere bürünmüş, gümüş saçlarını denize daldırmış, fettan bir dilber gibi yaslanan, Antalya'sında, kanadı kırık martı gibi karaya vurdum. Hiçbir yeri, hiçbir kimseyi bilmiyorum. Cep delik, yürek Selanik." Bir başka değerlendirmesinde ise "Bu şehrin yazı cehennemdir. Denizin kıyıcığında olduğu halde, falezlerle ondan uzaklaşmış, ona arka çevirmiş. Yörümek iş yapmak değil ya oturduğumuz, hem de çıplak oturduğumuz halde, sucuk gibi ter içinde kalıyoruz" demektedir. Tabakoğlu Süleyman Nuri Efendi, yılın sonuna doğru Antalya'ya Mutasarrıf olarak atanan Bodrumlu ve aynı zamanda köylüsü olan Hilmi Bey hakkında hatıratında şöyle yazmaktadır: "Bir gece, mütalaa saatinde, ayağında çizme, başında kalpak, uzun boylu, yarı sivil, yarı asker, yağız çehreli, ciddi ve sert bakışlı biri çıkageldi. Mutasarrıf (Vali) imiş (Hilmi Bey), hemen ayağa kalkarak selamladık. Her gece yalnı başına kol gezermiş. Bazı çocukları kaldırdı, bir şeyler sordu." Sıra bana gelince adımı ve nereli olduğumu sordu. Adımın Kaya (Bu dönemde İstihbarat Müdürü ve Fransızca hocası Aşkı Nailî Bey'in etkisiyle talebeler Arapça adlarımızı atarak, atalarımızın adlarını aldık. Kaya da benim adım oldu) olduğunu ve Bodrumlu olduğumu söyledim. Niçin şimdiye kadar bana gelmedin, bu ne biçim hemşerilik dedi. Senin amcanla benim İzmir'de geçmişim, ahbaplığım vardı. Bir derdin, bir isteğin olursa her vakit bana gel dedi. Teşekkür eden Tabakoğlu Süleyman Nuri, Mutasarrıf'ın köylüsü olduğunu bildiğini, ancak gençlik kafası, yiğitlik ruhu ile gitmediğini belirtir. Ancak 1923 yazında Antalya Darülmuallimin'i lağvedilince bir Temmuz günü Mutasarrıf'ın maddi yardımı ile vapura binip memleketine gidebildiğini hatıratına yazar. ${ }^{19} \mathrm{Hilmi}$ Bey'den birkaç ay sonra Antalya Menzil Hastanesi Başhekim ve Operatörü olarak Konya'dan şehre gelen (2 Şubat 1922) Dr. H. Burhanettin Bey (Onat), hatıratında geldiği zaman Mutasarrıf Hilmi Bey'in yeni göreve başladığını, tedbirli ve ağır başlı bir devlet adamı olduğunu belirtir. Ayrıca İtalyanların şımarıklıklarına ve Yunanlıların küstahlıklarına tam bir devlet adamına yakışır karşılıklar verdiğini ifade eder. ${ }^{20}$

\section{2- Faaliyetleri}

İcra Vekilleri Heyeti 18 Haziran 1920 tarihli kararı ile Antalya ve Mudanya iskelelerini Anadolu'ya gelecek yabancılar için giriş kapısı kabul etmiştir. ${ }^{21}$ Bu kapsamda Fransız gazeteci Berthe Georges Gaulis 20 Mart 1921 tarihinde Antalya'ya geldiğinde "işste milliyetçi Türkiye'nin giriş kapsı, Italyanlar buranın fahri kapıcılığını yapıyorlar, ama Ankara'nın izni olmadan buradan içeriye bir atamazsını" diyordu..22 Madam Gaulis'in

17 Macit Selekler, a.g.e. , s. 157-158.

18 Antalya Darülmuallimin-i İptidaiye için bakınız: Muhammet Güçlü, “Antalya Darülmuallimin-i İptidaiye (19031923)", Selçukludan Cumhuriyet'e Sosyal Bilimlerde Antalya I, Ed. Bedia Koçakoğolu-Bahset Karslı vd. , Antalya, 2018, s. 282-302.

19 Tabakoğlu Süleyman Nuri Öz, Bu Nasıl Adam? Bir Öğretmenin Anıları, İstanbul, 1971, s. 27-37, 57.

20 Burhanettin Onat, Bir Zamanlar Antalya-Bir Antalya Sevdalısının Kaleminden, İstanbul, 2000, s. 96; Muhammet Güçlü, Dr. H. Burhanettin Onat ve Hayat (1894-1976), Antalya, 2004, s. 28-29.

21 Başbakanlık Cumhuriyet Arşivi, 030.18.01.01.1.3.20.

22 Berthe Georges Gaulis, Kurtuluş Savaşı Sırasında Türk Milliyetçiliği, Çev. Cenap Yazansoy, İstanbul, 1981, s. 123. 
bu vurgusunu Hollandalı gazeteci George Nypels "Kemalistan'a ana girişti", Amerikalı gazeteci Clarence K. Streit "Antalya ana limandır" ve İngiltere'nin İstanbul'daki Yüksek Komiseri Sir H. Rumbold, 27 Nisan 1921 tarihinde Londra'ya gönderdiği 1920 Yıllık Raporu'nda "Ankara ile Batı Avrupa arasındaki temel bağlantı Antalya'dan geçmektedir" diyerek tekrarlamaktadırlar. ${ }^{23} \mathrm{O}$ dönemde Anadolu'nun giriş kapısı olarak nitelenen Antalya'ya Mutasarrıf olan Hilmi Bey, Antalya'ya gelir gelmez sorunlarla boğuşmaya başladı. Bunun başında da Antalya iskelesinden cepheye sevk edilen mühimmatın gönderilmesi geliyordu. Ayrıca asker sevkıyatı da önemli bir konu idi. Doğal olarak işgal ettiği makam gereği yapacağı rutin işler de vardı. Bu arada Antalya Anadolu gazetesinden öğrendiğimize göre Antalya Hilal-i Ahmer Cemiyeti'nin başkanlığını da yürütüyordu. Çünkü Cemiyet 3 Nisan 1922 tarihinde Belediye dairesinde Reis-i evvel Mutasarrıf Hilmi Bey'in başkanlığında kongresini yapmıştır. Bu kongre cemiyetin ilk kongresi olup, önceki sene görev alan heyet-i merkeziye azasının hesaplarını inceleyen komisyon raporu okunmuş, rapordaki ufak tefek usul hataları düzeltildikten sonra kabul edilmiştir. Ayrıca yeni heyet-i merkeziye azası seçilmiştir. Seçilen azalar arasında Mutasarrıf Hilmi Bey, Belediye Reisi Hakkı Bey, Antalya'da Anadolu Gazetesi sahibi Haydar Rüştü Bey ile şehrin ileri gelenleri bulunmaktadır. Yapılan görev dağılımında bu sefer Mutasarrıf Bey görev almamış olup, cemiyetin birinci başkanlığına Antalya eski Müftüsü Ahmet Hamdi Efendi seçilmiştir. ${ }^{24}$ Ahmet Hamdi Efendi'nin başkanlığı sırasında Hilal-i Ahmer'in yaptığı en önemli iş beklide Batı Cephesi Sıhhiye Reisliği'nin yirmi kadar sedye isteğine 400 adet alüminyum Amerikan portatif sedyesi ile karşılık vermesi idi. ${ }^{25}$ Mutasarrıf Hilmi Bey, 2 Ocak 1922 tarihinde Heyet-i Merkeziye azasından tüccardan Mehmet Remzi Efendi'ye yazdığı bir yazıda Antalya hastaneleri adına Hilal-i Ahmer'ce tedarik edilecek eşyanın alınmasında cemiyetin ikinci reisi Ahmet Hamdi Efendi ile hareket etmesini ve 15 Kasım 1922 tarihli bir başka yazıda ise Antalya Muaveneti iç̧timaiye Cemiyeti Hayriyesi'nin boş olan heyet-i idare azalığına seçildiğini bildirmektedir. ${ }^{26}$

Bu arada yeni bir zaferin hazırlıkları sürdürülürken asker kaçakları konusu da hükümetin sıkı takibi altındaydı. Antalya'ya bir İstiklal Mahkemesi gelmiş ve birkaç asker kaçağını asmıştır. ${ }^{27}$ Mutasarrıf Hilmi Bey'in sözünü ettiği mahkeme Konya İstiklal Mahkemesi olup, Karesi Mebusu Hacim Muhittin Bey'in başkanlığında 19 Nisan-11 Haziran 1922 tarihleri arasında Antalya'da çalışmıştır. Mahkeme Antalya'da altı idam kararı verip, gümrük yolsuzluğu ve kaçakçılık konusuna dikkat çekmiştir. Dahiliye Vekaleti'nden sahil korumaya önem verilerek dürüst kişilerin gümrüklerde görevlendirilmesini istemiştir. ${ }^{28}$ Mahkeme başkanı Hacim Muhittin Bey hatıratında Antalya'da görev yaptığı sırada hakkında sekiz on dosya olan Arap Murat'ın yargılandığını ve idamının öldürdüğü yaşlı kadının evinin önündeki ağaca asılmak suretiyle gerçekleştiğini anlatmaktadır. ${ }^{29}$ Mahkemenin diğer idam kararlarını da Batı Cephesinde görevli Mülazım Mustafa Hulusi'nin (Ersöz) günlüğünden öğreniyoruz. Çünkü Mülazım Mustafa Hulusi Efendi, günlüğünün 11 Haziran 1922 tarihli kısmına memleketten (Antalya, Serik) 28. 5. 1922 tarihli bir mektup aldığını, Zaimler köyünden Cemali ile Mandırla köyünden Gök Ali, Dairi, Fade'nin Halil adlı melunların İstiklal Mahkemesi tarafından idamlarına karar verildiğini ve Ramazan ayının ortasında ikisinin, bayramın ilk günü de diğerinin cezasının ifa edildiğini yazmaktadır. Ama dördüncüsünün akıbeti hakkında malumat vermemektedir. ${ }^{30}$

23 Muhammet Güçlü, "Milli Mücadele Döneminde Hollandalı Gazeteci George Nypels'in Anadolu İzlenimleri (Aralık 1920-Mart 1921)" , Cumhuriyet Tarihi Araştırmaları Dergisi, S. 19, Bahar 2014, s. 124-125.

24 Antalya'da Anadolu, 5 Nisan 1338.

25 Muhammet Güçlü (2004), a.g.e., s. 32.

26 Süleyman Fikri Erten, Milli Mücadelede Antalya, Antalya, 1996, s. 42, 47.

27 Hilmi Uran, a.g.e., s. 138.

28 Muhammet Güçlü, XX. Yüzyılın IIlk Yarısında Antalya, Antalya, 1997, s. 19.

29 Turgut Çarıklı, a.g.e. , s. 158-159.

30 Mülazım Mustafa Hulusi, Bir Kalpaklının Milli Mücadele Günlügü, Yay. haz. Bayram Kodaman-Fahrettin Tızlak, Isparta, 2006, s. 119. 
Mutasarrıf Hilmi Bey, Büyük taarruz öncesi Ankara'dan aldığı şifre üzerine Antalya'da bulunan İtalyan telsizinin antenlerini indirtip, kapısına bir posta koymuştur. Mutasarrıf nezaketen İtalyan konsolosuna telsizin indirileceğini söylediği zaman muhatabı Mersin'de bulunan Fransız telsizinin indirilip indirilmeyeceğini sormuştur. İndirileceği cevabını alınca pek memnun olmuştur. Böylece artık Anadolu her tarafla her türlü bağlantısını kesmiştir. Büyük Taarruz'u Teke Mutasarrıfı olarak yaşayan Hilmi Bey, cephe tebliğleri ile savaşın durumunu takip ediyordu. ${ }^{31}$ Antalya Menzil Hastanesi Başhekimi Dr. Burhanettin Bey, İtalyan telsizinin durumu ve sonrasın yaşananlar konusunda şöyle demektedir: Ankara hükümetinin emri gereği Antalya Mutasarrıfı Hilmi Bey, 25 Ağustos 1922 tarihinde Karaalioğlu bahçesinin giriş kısmında Stadyumun bulunduğu yerde kurulu olan İtalyan telsizini kumandan Batçi'den teslim aldı. Telsizin direkleri indirildi ve etrafına nöbetçiler yerleştirildi. Bu arada Antalya iskelesine gelen Hidiviye Kumpanyası'na ait vapurdan karaya çıkmak isteyenler, liman başkanı tarafından emir gereği karaya çıkarılmadı. Bu çalışmalar Büyük Taarruz'un ilk işareti olarak algılandı. Şehre yapılan resmi tebliğlerde bazı askeri harekâttan söz ediliyor, ancak ayrıntı verilmiyordu. Daha sonra Antalya'ya bir yandan Sandıklı'dan yaralılar gelirken öbür yandan şenlikler yapılıyordu. ${ }^{32}$ Süleyman Fikri Bey'in aktardığına göre ise Antalya gazetesi, Gazi Ordu Mücahitlerine armağan edilmek üzere Antalya tarafından altın kaplama direkli ve serapa altından mamul ay-yıldızlı bayrağı ve İzmir Kordon'da kesilecek 125 koyun ile 20 dana hazırlandığını, Mebus Rasih, Karahisar Mebusu Hulusi, Polis Müdürü Nuri, Liva Encümen Azası M. Emin, Ticaret Odası Reisi Zeki ve bazı tüccarların bulunduğu bir heyet tarafından Luid Triestina vapuru ile İzmir'e götürüldüğünü yazıyordu. ${ }^{33}$ Ekim 1962 tarihinde Antalya gazetesinde konuya ilişkin hatıralarını yazanlar biraz farklı olmakla birlikte İzmir programı hakkında ayrıntı bilgiler vermektedir. ${ }^{34}$ Bu arada Büyük Taarruz sonrası 19 Eylül 1922 tarihinde Türkiye Milli İthalat ve ihracat Şirketi 54 Milletvekili, 37 tüccar, bazı yüksek memur ve subaylar tarafından kuruldu. İngiliz sermayesiyle imtiyaz kokan bir anlaşma imzalamaya teşebbüs eden şirketin kurucuları ve yöneticileri arasında Yunus Nadi, Şükrü Kaya, Ali Bey (Çetinkaya), Kılıç Ali, Hilmi Bey (Uran), Mustafa Şeref (Özkan), Tunalı Hilmi, Soysalıoğlu İsmail Suphi gibi siyasiler ve bürokratlar yer alıyordu. ${ }^{35}$ Teke Müstakil Mutasarrıflı görevini ifa eden Hilmi Bey, bu teşebbüsüyle Muğla Mebusluğu sonrası giriştiği ticari faaliyetlerden ders almamış gibi gözüküyor. Çünkü hem Milas'ta ailesiyle beraber yürüttüğü ticari faaliyetleri hem de Türkiye Milli İthalat ve İhracat Şirketi ile giriştiği teşebbüs hüsranla bitmiştir.

Rum Muhaceratı: Büyük Taarruz sadece Yunan ordusunu Anadolu'dan atmamış, aynı zamanda Anadolu Rumlarının da yurtlarını terk etmesi sonucunu doğurmuştu. Balkan savaşı sonrası Çeşme Rum Muhacereti'nin yöneten Hilmi Bey, tecrübeli bir yönetici olarak Milli Mücadele sonrası yaşanan Rum muhaceretini bir hafta içinde tamamlamıştır. Bu sırada Burdur ve Isparta Rumları en yakın iskele olarak eşyalarıyla beraber Antalya iskelesine gelmişlerdir. Antalyalı Rumlar da evlerinde vapur beklemek yerine eşyalarıyla iskeleye akın etmişler. Bu dönemde altın dışında eşyalarını almalarına izin verilen Rumların çeşitli yollarla altın kaçırma girişimlerinde bulundukları görülmüştür. Amerikalılar, Rumların nakliyesini sağlamak için torpidolar eşliğinde Antalya körfezine özel vapurlar göndermiştir. Büyük tonajlı vapurlar Antalya iskelesine yanaşamadığı için açıkta demirlemek durumundaydı. Mavnalar aracılığıyla önce insanlar sonra eşyalar vapurlara taşınmaya başlandı. Özellikle eşya taşımak uzun sürdüğü için kaptanlar "Biz buraya bagaj taşımak için gelmedik" diyerek eşya almayı ret ederek demir almışlardır. Böylece Rumlara ait bir kısım eşya iskelede kalmıştır. Maliye tarafından el konulan eşyalarda yapılan incelemede üzeri kumaşla kaplı düğme haline getirilen, yumak haline getirilmiş yün iplikler içine gizlenmiş ve yorgan dikişlerine gizlenen bir hayli altın bulunmuştur. Antalya'nın yanında Alaiye,

31 Hilmi Uran, a.g.e. , s. 138-139.

32 Burhanettin Onat, a.g.e., s. 99-100.

33 Süleyman Fikri Erten, a.g.e. , s. 68-69.

34 Evren Dayar, Antalya Belediye Tarihi 1868-1923, Antalya, bty. , Antalya Büyükşehir Belediyesi Yayınları, s. 87. 35 Korkut Boratav, Türkiye'de Devletçilik, Ankara, 1982, 2. bs. , Savaş Yayınevi, s. 20-21. 
Manavgat ve Finike iskelelerinde de Rum muhacereti yaşanmıştır. Hilmi Bey, Burdur ve Isparta'dan gelenlerin Rumca bilmediklerini, çocukların büyüklerini Marya hala, Despina teyze diye Türkçe çağırdıklarını belirtiyordu. Ancak bunlar, XIX. yüzyılda Yunan Megalo İdeası'nın Anadolu'ya yayılmış mayası olarak görüldüler ve Anadolu için beslenen Yunan hayalleri, bunların oradaki varlığına dayanır oldu. Rum kilisesi de Yunan emellerinin en sadık destekleyicisi haline getirildi. Buna bir de genç papazlar ile öğretmelerin anavatan olarak Yunanistan'ı tanıtan telkinleri eklenince Rum ve Müslüman halk arasında bir güvensizlik hâsıl oldu. ${ }^{36}$ Rum muhaceretine ait resimlerden sadece Antalya İskelesi'nde 8000 mültecinin ayrılmak için beklediği anlaşılmaktadır. ${ }^{37}$ Bu rakama Alaiye, Manavgat ve Finike iskelelerinden gidenlerde ilave edilmelidir.

Antalya'da boş kalan Rum evleri ile eşyalarının derlenip toplanması sırasında emniyet ve asayişi sağlama işi önem arz etmişti. Kasabada yeterli polis ve jandarma yoktu. Sadece kasabada bir depo alayı vardı, o da sık sık acemi er alıp kısa bir talimden sonra onları cepheye sevk ediyordu. Çarşı içinde çıkan küçük bir olay daha büyüklerinin habercisi idi. Bu alayın kasaba dışına çıkarılması gerekli olup, bu konuda Mutasarrıf Hilmi Bey'e telkinlerde gelmeye başlamıştı. Mutasarrıf Bey, alay kumandanına yazdığı tezkerede emniyet ve asayişin kasabada aldığı ehemmiyeti belirttikten sonra alayın dört beş km. uzaklıkta bulunan bir çiftlik evi müştemilatına gayet acele kaydı ile çekilmesini bildirdi. Ayrıca tezkereye bu nakil işleminin yirmi dört saat içinde yapılmazsa derhal örfi idare ilan edileceğini, bunun sorumluluğunun da alay kumandanına ait olacağını eklemişti. Bunun üzerine alay kısa bir zaman içinde sözü edilen çiftlik binalarına yerleşmiştir.

Hilmi Bey'in İdadi Mektebi'nden itibaren sınıf arkadaşı olan Safa (Apaydın) Bey, Burdur Mutasarrıflığı görevine gelmiştir. Safa Bey, Burdur Gölü’nde balık yetişip yetişmeyeceğini denemek için resmi yazı ile bir miktar balık istemiştir. Gölün tuzlu ve kısmen arsenikli olduğunu duyan Hilmi Bey, iki kutu sardalya balığı gönderip, kutuya iliştirdiği resmi yazıda "Bu balıklar tuza alışık olduklarından tecrübenizde belki daha iyi bir başarı sağlar" demiştir. ${ }^{38}$ Bu arada 12 Eylül 1922 tarihli Antalya'da Anadolu gazetesinde yer alan "Encümen Mukarreratı" başıklı haber Gureba Hastanesini konu edinmekteydi. Buna göre Encümen-i Liva tarafından hastaneye bir gusülhane ile bir ameliyathane yapılması kararlaştırıldığından projenin Mühendis Salih Bey tarafından yapılmasına karar verildi. Ayrıca 1922 bütçesine ödeneği konulan hastane kubbesi önüne konulacak olan camekânın onbeş gün süre ile ihaleye çıkarılmasına, hastanenin kapanmış olan hela ile çamaşırlığının yeniden açılmasına, ambar penceresi ile kırılan panjurların tamirine ve pansuman odasına lavabo takılmasına, bu işler için onbeş bin kuruş avans verilmesine, söz konusu işlerin Encümen-i Liva azası Ali Efendi'nin nezareti altında müzayede ile yapılmasına karar verilmiştir. ${ }^{39}$

Içme Suyu: Büyük Taarruz'dan aylar önce Hakimiyet-i Milliye gazetesinde yayınlanan "Antalya Suları" başlıklı haberde "Antalya şehrine kabil-i şurub sular getirmek üzere tetkikata memur edilen Mühendis tetkikatını ikmal etti. Liva Mutasarrıfı (Hilmi Bey) başkanlığı altındaki komisyonda Antalya suları hakkında müzakerat cereyan etti" denilmektedir. ${ }^{40}$ Ancak bu ve bundan önce yapılan incelemeler bir yıl sonra semeresini vermeye başlamıştı ki bu seferde Mutasarrıf'ın tayini Adana'ya çıkınca başarısız oldu. 29 Ekim 1921-22 Temmuz 1923 tarihleri arasında görev yapan Hilmi Bey, hatıratında güzel Antalya şehrinin en büyük noksanı olarak temiz bir içme suyu bulunmamasını görüyordu. Kasaba yaz kış içlerinde su bulunan kanalları ile bir su memleketi olarak görülebilirdi. Fakat bu kanalların üstü açık olduğu için sağılılı değildi. Bu su ile halk her

36 Hilmi Uran, a.g.e. , s. 142-145.

37 www.levantineheritage.com/adalia.htm, Erişim Tarihi: 15. 01. 2016.

38 Hilmi Uran, age. , s. 146-147.

39 Antalya'da Anadolu, 12 Eylül 1338.

40 Hakimiyet-i Milliye, 10 Mayıs 1338. 
çeşit meyve ve sebzeyi yetiştirdiği bahçelerini suladığı gibi aynı zamanda onların büyük bir kısmı tarafından içme suyu olarak da kullanıyordu. Bu yüzden kasabada tifo, dizanteri gibi salgın hastalıklar eksik olmuyordu. Halk kanal suyunun dışında evlerindeki kuyu ve yeraltı suyundan da yararlanıyordu. Ancak bu kaynaklar da ya kirli ya da sertlik derecesi yüksek sulara sahipti. Sınırlı bazı evlerde sarnıçlar bulunmakta olup, Mutasarrıf Bey de bu kaynağı kullanmıştır. Su sorununu derinden hisseden Hilmi Bey, araştırmaları sonucu civarda içmeye uygun ve yeterli bir kaynak suyu bulmuş ve Hüseyin Rıfkı Bey adında bir Su Mühendisi ile irtibat kurarak onunla bir isale projesi için anlaşma yapmıştır. H. Rıfkı Bey projesini tamamladıktan sonra Belediye ve Özel idare'den sağladığı kaynak ile boruları ısmarlamıştır. Mutasarrıf'ın Adana valiliğine terfian tayini üzerine Antalya'dan ayrıldığı gün limanda iki vapur vardı. Bunlardan birisi Hilmi Bey'i Adana valiliği için Mersin limanına götürecek olan Antioch vapuru, diğeri ise ecnebi bandıralı bir şilep olup Antalya içme suyu için ısmarladığı su borularının birinci kısmını getiren vapur idi. Bu vapurun vinçleri sürekli çalışmakta ve yanına yanaşmış olan mavnalara su borularını yüklemekteydi. Hilmi Bey kendisini uğurlamaya gelen kasabanın ileri gelenlerine yarıda kalmış bu projeyi tamamlamayı emanet etmiştir. Kendisinden sonra Antalya'ya yakından tanığı kişilerin atandığını duyunca içme suyu projesinin yarıda kalmayacağı düşüncesine kapılmıştı. Ama yanılmıştı. Çünkü Antalya içme suyu projesi senelerce yapılmamış ve su boruları da kasabanın sokaklarına atılmış kalmıştı. ${ }^{41}$ Antalya şehrine Vali Sahip (Örge) Bey zamanında Hurma köyünden ve Vali Haşim İşcan döneminde Tekirpınarı'dan içme suyu getirme girişimi başarısız oldu. Vali Haluk Nihat Pepey zamanında "Yayla Suyu Derneği" kurularak Tekirpınarı'ndan su getirme girişimi sürdürüldü. Vali Sadri Aka zamanında Tekirpınar'ı suyunun maliyetinin yüksekliği göz önüne alınarak Hurma köyünde bulunan Soğucak Pınar suyu, Konyaaltı ve Bahçelievler'e, Vali i̇. Hakkı Baykan (1949-1950) döneminde ise Memleket Hastanesi, Saat Kulesi ve Paşa Camii dibine getirilerek üç çeşmeden akıtıldı. ${ }^{42}$ Böylece Hilmi Uran'ın emaneti geçte olsa belki de bir seçim yatırımı olarak gerçekleşmiş oldu. Ama şehre su getirme hadisesinin çeyrek asırdan fazla sürmesi Yanık Ömer'in şu dizelerine konu olmuştur. Yanık Ömer'in Antalya'ya su getirme konusunda Hilmi Uran ile Saip Örge'nin faaliyetlerinden haberi olmadığını ilave edelim.

"Aşkından kebap olduk, hasretinden sarardık.

Ölsek de uğrunda ey nazlı su gelmek bilmez.

Nice İscan, Pepey'i uğrunda telef oldu.

Bir aşkın da Aka, su bizi sevmek bilmez." ${ }^{\prime \prime 3}$

\section{B- Antalya'da II. Dönem Mebus Seçimi}

\section{1- Antalya'da Seçim Hazırlıkları ve Müdafaa-i Hukuk Cemiyeti İdaresinin Feshi}

Hilmi Bey Teke Mutasarrıfı olarak görev yaparken, 1 Nisan 1923 tarihinde TBMM seçimlerin yenilenmesine oy birliği ile karar vermiştir. Mustafa Kemal Paşa'nın 8 Nisan 1923 tarihinde yayınladığı dokuz maddelik seçim beyannamesi kapsamında Antalya Müdafaa-i Hukuk Cemiyeti merkezinde bazı toplantılar yapıldığı anlaşılmaktadır. Çünkü Müdafaa-i Hukuk Cemiyeti Antalya Heyet-i Merkeziye Reisi Hasan Sıtkı imzası ile 6 Mayıs 1923 tarihinde Heyet-i Merkeziye azasından Mehmet Remzi Efendi'ye gönderilen 41 nolu yazıda "Anadolu ve Rumeli Müdafaa-i Hukuk Cemiyeti Reisi Mustafa Kemal Paşa Hazretleri'nin intihabat-ı mesaisi hakkındaki emirname-i samilerinden ve ahiren müşarünileyh tarafından neşir buyurulan umdelerden anlaşıldığına nazaran intihabatın Müdafaa-i Hukuk Cemiyetleri etrafında cereyanı muhakkak olmasına binaen, husus-u

41 Hilmi Uran, a.g.e. , s. 149-151.

42 Muhammet Güçlü (1997), a.g.e. , s. 82.

43 Ağam Mizah Mecmuası, C. 1, S. 1, Ocak 1948, s. 4. 
mezkur hakkında ariz ve amik müzakerede bulunmak üzere bu gün akşam alaturka saat 2.30'da Belediye'de vaki Cemiyet dairesine behemahal teşrif buyurulmasını rica ve bilvesile teyid-i hürmet olunur efendim" denilmekteydi. ${ }^{44}$ Bu arada Muğla halkı 300 imzalı bir dilekçe ile Teke Mutasarrıfı Hilmi Bey’i Muğla Mebusluğu'na aday göstermiştir. Hilmi Bey adaylık durumunu haber alınca hemen bir telgraf ile Büyük Millet Meclisi Reisi Mustafa Kemal Paşa'yı haberdar etmiştir. Paşa, cevabi telgrafında adaylığını iyi karşılıyor ve inşallah muvaffak oluruz diyordu. Ancak bir süre sonra Mustafa Kemal Paşa'nın Muğla adayları arasında kendi ismini göremeyince, onunla rekabet etmemek için derhal adaylıktan çekildiğini Muğla'ya bildirmiştir. ${ }^{45}$

Anadolu ve Rumeli Müdafaa-i Hukuk Cemiyeti Reisi sıfatıyla Gazi Mustafa Kemal Paşa, 2 Haziran 1923 tarihinde Müdafaa-i Hukuk Cemiyeti ve Halk Fırkası'nın seçim çalışmalarına dair yayınladığı tamimde, Anadolu ve Rumeli Müdafaa-i Hukuk Cemiyeti’nin ve Halk Fırkası'nın seçim çalışmasını kusurlu göstermek amacıyla kötü amaçlı bazı kişiler tarafından kötü haberler yayıldığını, henüz hiçbir yerde Mebus seçimine başlanmamış olduğu halde bazı livalarda Müdafaa-i Hukuk adaylarının kaybettiği şeklinde memleketin bazı mıntıkalarında propagandalar yapıldığını, merkezden henüz adayları gösterilmeyen bazı yerlerde Cemiyet ve Fırka adına bazı isimler açıklandığı gibi merkezce adayları tespit ve mahalline bildirilen bir livada da listeye hariçten bir isim sokulduğunu bildiriyordu. Ayrıca yeni oluşturulacak TBMM'nin memleketin geleceği üzerine hayati bir etki ve ehemmiyete haiz bulunduğunu, bütün vatandaşların bu ve bu gibi telkin ve tesir hakkında uyanık bulunmalarını temin için bu açıklamayı yaptığını belirtiyordu. Artık memleketin bütün kısımlarında seçimin kesin faaliyet devresine girildiğinden seçme yetkisini, birinci seçmenlerden uhdelerine alan ikinci seçmen arkadaşlarımın da vatanın kesin kurtuluşu ve yükselmesini temin eden yol üzerinde hareket edeceklerinin tamamen şüphesiz olduğunu ilave ediyordu. ${ }^{46}$

$\mathrm{Bu}$ arada Meclis'te muhalif mebuslar bir yerde beş yıl oturmayanların mebus seçilemeyeceğine dair bir önerge verdiler. Mustafa Kemal Paşa, bu konuyla ilgili milletin fikrini almak istediği için çeşitli illerde olduğu gibi Antalya'da da bir miting düzenlenmiştir. Antalya Darülmuallimin talebesi Tabakoğlu Süleyman Nuri Efendi, Antalya mitingi hakkında şunları yazmaktadır: Bütün öğrencileri Hükümet önündeki toplantıya götürdüler. Alanı dolduran halkın yüzünde üzüntü çizgileri görülüyordu. Tertip heyetinin programına göre söylevler verildi. "Halk coşmuş, heyecan içinde, bağırıyor; hainler kahrolsun! Biz Mustafa Kemal'i isteriz" diyordu. Miting havası içinde heyecana gelen Darülmuallimin talebesi Süleyman Nuri Efendi, "Büyük kurtarıcıyı istemeyenler kahrolsun, biz de onları istemiyoruz. İçimizdeki, dışımızdaki bütün düşmanlarımız bilsin ki, Mustafa Kemal olmasa da savaşa devam edeceğiz ve mutlaka istiklalimizi kurtaracağız. Bu millet her zaman bir Mustafa Kemal çıkaracaktır. Yaşasın Mustafa Kemal!" diye bağırdı. Bunun üzerine tertip heyetinden Nalbantoğlu Hıfzı Bey, postanenin merdiveninden haykırdı: "Kimdir o? Susturun şunu, miting programı dışında kimse konuşamaz" dedi. Ertesi gün Antalya mitingini anlatan Anadolu gazetesi şöyle yazıyordu: “... Bu esnada gök gürler gibi bir ses, irticalen söze başladı. Sonradan anladığımıza göre Muallim Mektebi ikinci sınıf talebesinden Kaya adındaki bu genç halkı büsbütün coşturdu." ${ }^{47}$ Miting tertip heyetinde İzmir'in meşhurlarından Nalbantoğlu Hıfzı Bey'in olması ve miting haberinin bir dönem Antalya'da da yayınlanan Haydar Rüştü Bey'in yönetimindeki Anadolu gazetesinde yayınlanması bu mitinglere İzmirlilerin önderlik ettiğini düşündürmektedir.

44 Süleyman Fikri Erten, a.g.e., s. 38-39.

45 Hilmi Uran, a.g.e. , s. 148-149.

46 Atatürk'ün Tamim, Telgraf ve Beyannameleri, C. 4, Ankara, 1991, Atatürk Araştırma Merkezi yayını, s. 535536.

47 Tabakoğlu Süleyman Nuri Öz, a.g.e. , s. 39-40. 
1923 yılı Haziran ayında Antalya Seçim Teftiş Heyeti ile Belediye Reisi Cemal Bey, ${ }^{48}$ ikinci Dönem Büyük Millet Meclisi'ne Antalya'dan Mebus seçilmek için başvuranları incelediler ve seçilmeye kanuni engeli olmayanların adlarını açıkladılar. Bu listeye göre Antalya eski Müftüsü Yusuf Talat, Belediye eski Reisi Akif (Sarıoğlu), Hastaciğerzade Seyfullah, Oltu Bidayet Hakimi Antalyalı Raşit Efendizade Süleyman Adil, Belediye Tabibi Dr. Galip, Hafız Mehmet Beyzade Semih, Antalya Mekteb-i Sultani eski Müdürü Sadık Kemal, İbradılı Rüştü Efendi'nin oğlu Mehmet Arif, Elmalılı Ömer Lütfü, Çanakkale Sıhhıye Müdürü Cemil Süleyman, Antalya Mebusu Halil İbrahim, Dr. Emin Salih, Korkuteli eski Kaymakamı Numan, Heyet-i Temyiziye azasından Akseki'nin Gödene köyünden Şemsettin Efendizade Osman Zeki, Diyarbakır Sıhhıye Müdürü Elmalılı Dr. Ferruh Niyazi, Bodrum Mahkeme Reisi Ali Haydar, Antalya Jandarma eski kumandanı Tahsin ve İzmirli Mahmut Hıfzı Bey ${ }^{49}$ Mebus seçilebilmek için Antalya'dan adaylık başvurusu yapmışlardı. Başvuranlara şöyle bir göz attığımızda bunların Milli Mücadele döneminde Antalya'da görev yapan doktorlar, kamu görevi ifa edenler ile vilayetin eşraf ve aydınlarından oluştuğunu görmekteyiz. Ama bu arada Antalya Müdafaa-i Hukuk Heyeti'nin çoğunluğunun cemiyetin maksat ve arzusuna aykırı, kendi fikir ve hissiyatlarına tabi olarak davrandıkları gerekçesiyle, Müdafaa-i Hukuk Merkezi Heyeti İdare Reisi Gazi Mustafa Kemal Paşa tarafından Teke Mutasarrıflığı'na gönderilen 10 Haziran 1923 tarihli telgraf ile heyetin faaliyetine son verildiği ve yerine, faal ve amal-i milliyeyi liyakatlarıyla temsile kadir kişilerden oluşmuş yeni bir heyetin hemen teşkiliyle işe başlatılması emredilmişti. ${ }^{50}$

11 Haziran 1923 tarihinde bir toplantı yapan Antalya Heyeti Merkeziyesi, Heyet-i Merkeziyemizin ilgası ve mühür ile evrak-ı resmiyenin hükümete teslimi hakkında Anadolu ve Rumeli Müdafaa-i Hukuk Cemiyeti Reisi Gazi Mustafa Kemal Paşa Hazretleri'nin 10 Haziran 1923 tarihli telgraflarına istinaden vazife-i kitabet ve veznedarlığı uhdesinde bulunduran azadan Hüseyin Bey nezdinde saklanan bütün resmi evrak ve mührü hemen Mutasarrıflık makamına teslimi ve iradenin yerine getirildiği, cevabi olarak telgraf yazılması kararı almıştır. ${ }^{51}$ Bu karar gereği Antalya Müdafaa-i Heyet-i Merkeziyesi cemiyete ait mühür ve defterleri Mutasarrıf Hilmi Bey'e teslim etmiştir. Bunun üzerine yeni oluşturulan Antalya Müdafaa-i Hukuk Heyeti'nde Kandilzade Hasan (Sıtkı), Abdi Efendizade Hüseyin, Ticaret Odası Reisi Zeki, Belediye azasından Zühtü Beyzade Hasan, Ellibeşzade Hacı Hasan, Kesikcizade Mehmet yer almıştır. Yapılan toplantıda Heyetin başkanlığına Kandilzade Hasan (Sıtkı) Efendi, katip ve veznedarlık görevine Abdi Efendizade Hüseyin Efendi getirildi. Yeni heyet 12 Haziran 1923 tarihinden itibaren göreve başlad.. ${ }^{52}$ Yeni oluşturulan bu heyet Antalya Müdafaa-i Hukuk Cemiyeti'ne ait gelir-gider defterinin sonunda bulunan 12 Mayıs 1924 tarihli karara göre cemiyetin son heyeti olup, Müdafaa-i Hukuk Cemiyeti'nin Halk Fırkası'na dönüşmesi ile cemiyetin nakdi ve ayni varlığını katip ve veznedarı Hüseyin Bey

487 Mart 1922 tarihli Antalya'da Anadolu gazetesinin haberine göre bir süre önce Belediye Reisliği'ne Ziraat Müdürü Akif (Sarıoğlu) Bey seçilmişti. Ancak nedendir bilinmez bir ay sonra aynı gazete sütunlarında "intihap bitti" başlığı ile Belediye başkanlığı seçimi sonuçlarına göre en çok oy alan kişilerin adlarının sıralandığını görüyoruz. Bunlar Hakkı Efendi 817, Akif Bey 457, Yusuf Cemal Efendi 441, Hafiz Celal Efendi 439, Şekerci zade Ali Efendi 435, Zeki Bey 432, Ellibeş Mehmet Ali Efendi 414, Hacı Vasili Efendi 407, Kaçaralaki Süleyman Efendi 384, Mehmet Kapudan 374, Haydar Şadi (Rüşdü) Bey 363, Vergi Başkatibi Hüseyin Efendi 339 oy aldı. Antalya'da Anadolu, 8 Nisan 1338. Hilal-i Ahmer Antalya Şubesi'nin kongresine ilişkin bir haberden anladığımıza göre 3 Nisan 1922 tarihi itibariyle en çok oy alan Hakkı Efendi, Antalya Belediye Reisi olarak seçilmiştir. Antalya'da Anadolu, 5 Nisan 1338. Ama 1923 yılı Haziran ayı itibariyle Antalya Belediye Reisi'nin 441 oy alan Yusuf Cemal Efendi olduğunu görüyoruz.

49 Feridun Kandemir yıllar sonra İzmir'e ilişkin yazdığı makalesinde Nalbantoğlu Hıfzı Bey'i “izmir'in kültür ve ticaret çevresinde pek tanınmış ve sevilmiş değerli simalarından kalendermeşrep ve hoşsohbet arkadaşı" olarak nitelemektedir. Uşakizade Muammer Bey ile yakın dost olan Hıfzı Bey, Ankara'nın ilk yıllarında sevilen, sayılan bir sima olup, İstanbul Kıraathanesi'nin kendine mahsus köşesinde çevresinde toplananlara eski günleri anlatırdı. Feridun Kandemir, "Ondokuzuncu Yüzyıl Sonlarında: İzmir", Tarih Konuşuyor, S. 29, Haziran 1966, s. 2414-2416. 50 Mustafa Üstün, "Antalya Tarihinden İzler", Atso Vizyon, S. 197, Haziran 2004, s. 32.

51 Süleyman Fikri Erten, a.g.e. , s. 38.

52 Mustafa Üstün, a.g.m. , s. 33. 
tarafından Halk Fırkası'nın katip ve veznedarı Hasan Basri Efendi'ye devir ve teslim ettiği anlaşılmaktadır. ${ }^{53}$

Antalya Müdafaa-i Hukuk Heyeti'nin feshinde, Gazi Mustafa Kemal Paşa'nın Meclis'te bulunmasını arzuladığı Rasih Efendi gibi kişiler etkili olmuş olmalıdır. Çünkü seçim döneminin başlarında Mustafa Kemal Paşa, Antalya Mebusu Rasih (Kaplan) Efendi ile Karahisar Mebusu Ali (Çetinkaya) Bey'i İstanbul'da Müdafaa-i Hukuk teşkilatını kurmaları için görevlendirmişti. Rasih Efendi ile Ali Bey daha önceden İstanbul'da görevlendirilen Yakup Kadri (Karaosmanoğlu) Bey ${ }^{54}$ ile çalışarak 2 Nisan 1923 tarihinde İstanbul'da Müdafaa-i Hukuk teşkilatını kurdular ve seçim çalışmalarına başladılar. ${ }^{55}$

Mustafa Kemal Paşa'nın iki bin lira maddi desteği ile 12 Haziran 1923 tarihinden itibaren Konya'da Halk adlı günlük bir gazete çıkaran Samizade Süreyya (Berkem) Bey, ${ }^{56}$ 17 Haziran 1923 tarihinde birinci sayfadan verdiği "Müdafaa-i Hukuk'a Sadakat" başlıklı haberde Antalya halkı ile Gazipaşa Müdafaa-i Hukuk Reisi Zihni'nin 12 Haziran 1923 tarihinde Müdafaa-i Hukuk Cemiyeti Reisi Mustafa Kemal Paşa'ya çekmiş oldukları bağlılık telgrafını yayınlanmıştır. Antalya'dan çekilen telgrafın altında Belediye Reisi, Ticaret ve Ziraat Odası Reisi ve İdare Meclisi azaları ile eşraftan birçok kimsenin imzası bulunmaktaydı. Halk gazetesi bu telgrafı yayınlarken imza yerine "Bir çok imzalar" ibaresini koymuştur. Önemine binaen telgrafları aynen veriyoruz.

“Memleketin ve milletin büyük müncisi Gazi Paşa Hazretleri:

Antalya Livası bidayet-i mücahededen bu güne kadar bütün Livalarla müsabaka edercesine fedakârlığı kendisine kurtuluş borcu bildi. Bu hususda kütle-i vahide halinde tecelli kendisine şiar edindi. Bütün hayatlarında menafi-i milliye ve vataniye uğrunda fedakarlıkdan uzak bulunan, muhalefeti kendilerine sanat-ı ittihaz eden sekiz onu geçmeyen eşhası ma'dude, Antalya Livası'nın zat-ı samilerinin riyaset buyurduğu Cemiyet etrafında ittihatlarına mani olamaz. Bu defa Merkez Müdafaa-i Hukuk'undan bir kısmının muhalefeti de bu nev'idendir. Müdafaa-i hukuk'un gaye-i hakikiyesini idrak edemeyen bu zevatın hey'etden uzaklaşması esasen pek rasin olan ittihadımızı bir kat daha takviye etmişdir.

Paşa Hazretleri! Henüz düşman işgalinden kurtarılan Livamız sekenesi nankör değildir, takdir vardır. Kurtarılan bütün vatan meyanında Livamız da fiilen istila sahası idi. Hüdapesendane celadetinizle yurdumuz kurtuldu. Muhakkak bir esaretden tahlis-i giriban eyledik. Tahlisiyle idrak etdiğimiz ni'metlerin içinde müstagrık iken Müdafaa-i Hukuk namına zat-ı samileri tarafından irae buyurulacak namzedleri müttefikan intihap etmez isek ni'met-i na-şinaslık etmiş oluruz. Bu ise Liva'mızın şiarına uygun değildir.

Paşa Hazretleri! Küçük, büyük Antalya Livası halkı Müdafaa-i Hukuk demekdir. Dört muhalifin içimizde yeri olmadığını ajans ile de müsaraat eder ve bütün muhalif fikir ve emel besleyenlerin nasiblerini başka bir hükümet arazisi dahilinde aramağı ihtara da müsaide-i samilerini rica ederiz."

Gazipaşa Müdafaa-i Hukuk Reisi Zihni ise çektiği bağlılık telgrafında şu görüşlere yer veriyordu. "Tarsus'da münteşir (Tarsus) gazetesinin 5 Haziran 39 (1923) tarihli nüshasında Livamız intihabatı pek hararetli gösteriliyor. Hatta yirmi rey ile bir mebus çıkacağını makam-ı iftiharda yazılıyor. Bu babda takib edilen maksad malumunuzdur. Mezkur gazeteve ve matbuata lazım gelen cevabı vereceğimizi bir daha arz ve ilan eyliyoruz. 53 Süleyman Fikri Erten, a.g.e. , s. 39.

54 Yakup Kadri Karaosmanoğlu, Politikada 45 Yıl, Ankara, 1968, s. 17-21; Samih Nafiz Kansu, Iki Devrin Perde Arkası, İstanbul, 1964, s. 526-527.

55 Işıl Çakan, Türk Parlamento Tarihinde II. Meclis, İstanbul, 1999, s. 34.

56 Caner Arabacı, Bünyamin Ayhan, Adem Demirsoy, Hakan Aydın, Konya Basın Tarihi, Konya, 2009, Palet Yayınevi, 2. Bs. , s. 185-192. 
Reylerimiz büyük Gazi'mizin göstereceği namzedlere aiddir. Zaman yakın, hak bizim, hacalet onlarındır, ferman." ${ }^{57}$

Bu telgraflar üzerine Gazi Mustafa Kemal Paşa, 14 Haziran 1923 tarihinde Teke Belediye Reisi Cemal Beyefendi ve rüfekasına çektiği telgrafta "Antalya halkının memleketin hal ve istikbalini yüksek bir idrak ile ihata ettiğine ve istihbaratta ve bu icabetin icrası dairesinde hareket edeceğine emin idim. Telgrafnameniz de bu kanaatimi teyit eyledi. Teşekkür eder ve takarrüb eden intihabat günlerinde aynı hararetle sarf-ı mesaide bulunulmasını temenni eder, muvaffakiyet temenni eylerim efendim" demektedir. Müdafaa-i Hukuk Cemiyeti ile Halk Fırkası'nın Antalya mebus adayları Haziran ayının ortasına doğru kesinleşmiştir. Mustafa Kemal Paşa tarafından Antalya Vilayeti'ne çekilen telgrafta "Allah'ın yardımı ile başlayacak olan mebus seçimleri için Müdafaa-i Hukuk cemiyeti ve Halk Fırkası mebus adayları aşağıdaki isimlerdir" denilmekte ve aday adları Rasih Efendi, Av. Giritli Ahmet Saki Bey, Alanyalı Şerif Alizade Murat Bey ve Müdafaa-i Hukuk Antalya Reisi Kandilzade Hasan Bey olarak sıralanmaktadır. ${ }^{58}$

\section{2- Antalya'da İkinci Dönem Mebus Seçimi}

Antalya Müdafaa-i Hukuk Cemiyeti tarafından ikinci dönem Mebus seçimlerinin olumlu bir havada geçmesi için bir "Mebus Seçimi Şenliği" hazırlanmıştır. Cemiyet programı halka duyurmuş ve katılmalarını istemiştir. Seçim günü yapılacak şenliğin programına göre Yenikapı'da toplanacak alay ile Çarşı'ya gelinecek ve her iki yerde konuşmalar yapılacaktır. Daha sonra alay Telgrafhane Caddesi'ni takiben Askerlik Dairesi arkasından ve Sıhhıye Dairesi önünden geçerek Hükümet Konağı önüne gelecektir. Burada da konuşmalar yapıldıktan sonra müntehib-i sanilerin (ikinci seçmenler) beklemekte olduğu Şafak Kıraathanesi önüne gelinecektir. Burada müntehib-i saniler alaya katılacak ve hep beraber seçimin yapılacağı Belediye önüne varılacaktır. Burada Mebus seçimleri yapılacak, nutuklar verilecek, şenlik ve donanma icra edilecektir. Bu arada çalgılar, davullar çalınacak, milli oyunlar oynanacaktır. Daha sonra alay Çarşı'ya geçecek, büyük cadde üzerinden Antalya Gazetesi önüne gelecektir. Burada yapılacak bir gösteriden sonra Şarampol'e geçilecek burada da nutuklar, manzumeler söylenecek ve alay sona erecektir. Gece de Gençler Yurdu ile Muallimin Cemiyeti tarafından Belediye önünde düzenlenen eğlenceler sabaha kadar devam edecektir. Bu amaçla mızıka, saz takımı, davul-zurna gibi bütün aletler temin edilmiştir. Ayrıca İskele esnafının hepsinin kudüm ve davulları da donanmaya katılacaktır.

Böylece Müdafaa-i Hukuk Cemiyeti Merkezi tarafından gösterilen dört aday 5 Temmuz 1923 tarihinde Antalyalıların seçtiği müntehib-i sanilerin onayına sunuldu. Antalya merkezindeki 102 müntehib-i saniden Kandilzade Hasan Sıtkı 84, Giridi Ahmet Saki 84, Rasih Efendi 83, Şerif Alizade Mahmut Murat 76, ${ }^{59}$ Latife Mustafa Kemal Hanım 7 ve Şerifzade Ahmet Bey bir oy aldı. Seçimlerde aday olmamasına rağmen kendisine oy verilen Latife Gazi Mustafa Kemal, Antalyalılara hitaben yayınladığı teşekkür mesajında "Mebuslarınızın seçimi sırasında bana da oy verilmiş olmasını Türk kadınlığı adına çok büyük sevinçle karşıladım. Muhterem ve yeniliksever halka selam ve çok teşekkür ederim" demekteydi. ${ }^{60}$ Teke Mutasarrıflığı genelinde yapılan ikinci dönem Mebus seçiminde Kandilzade Hasan Sıtkı Bey 359, Ahmet Saki Bey 357, Rasih Hoca 355, Şerif Alizade Mahmut Murat Bey 355 oy alarak Antalya Mebusluğu'na seçilmiştir. ${ }^{61}$ ikinci dönemde Antalya'dan seçilen dört Mebus'tan birisinin (Avukat Giridi Ahmet Saki Bey) Müdafaa-i

57 Halk, 17 Haziran 1339.

58 Evren Dayar, a.g.e. , s. 88-89.

59 Mustafa Üstün, “Antalya Tarihinden İzler”, Atso Vizyon, S. 198, Temmuz 2004, s. 39-40.

60 Evren Dayar, a.g.e. , s. 89.

61 Kazım Öztürk, Türk Parlamento Tarihi TBMM. II. Dönem 1923-1927, C. 3, Ankara, 1995, s. 89-95; Nebahat Oran, Antalya Milletvekili Rasih (Kaplan) Bey'in I. ve II. Dönem Türkiye Büyük Millet Meclisi'ndeki Siyasi Faaliyetleri, Atatürk Üniversitesi Sosyal Bilimler Enstitüsü Tarih Anabilim Dalı Yayınlanmamış Yüksek Lisans Tezi, Erzurum, 1997, s. 9. 
Hukuk Grubu'nun Mebus seçilmek için belirlediği ilkelerden bölge ahalisinden olma ilkesine uymadığı görülmektedir. Ama Giridi Ahmet Saki Bey'in listeye konulmasında ve 357 oy almasında Antalya merkez ve kazalarında yerleştirilmiş olan Giritliler etkili olmuş olmalıdır. ${ }^{62}$ Ayrıca Milli Mücadele taraftarı Celal Nuri Bey'in Illeri gazetesinde uzun zaman yazarlık yapması da etki etmiştir. ${ }^{63}$ Şerif Alizade Mahmut Murat Bey ise aslen Alanyalı olup İstanbul'da ticari faaliyetlerde bulunmaktadır. Yukarda belirttiğimiz üzere Ali Bey ile Rasih Hoca'nın İstanbul çalışmalarındaki katkılarından dolayı Antalya'dan aday gösterilmiş olsa gerektir. Buna benzer durumlar başka seçim çevrelerinde de yaşanmış olup, örneğin memleketi Manisa yerine Yakup Kadri Bey Mardin, Hakkı Tarık (Us) Bey ise Giresun'dan aday gösterilmiştir. ${ }^{64}$ Seçim bölgesi ahalisinden olma ilkesine Antalya'nın da içinde olduğu I. Bölge'de \% 48.06 oranında ve ülke genelinde ise \% 40.24 oranında uyulmadığı görülmüştür. ${ }^{65}$

İkinci dönem Mebus seçimleri büyük oranda tamamlandıktan sonra 18 Temmuz 1923 tarihinde Anadolu ve Rumeli Müdafaa-i Hukuk Cemiyeti Reisi Gazi Mustafa Kemal imzasıyla, Belediye ve Müdafaa-i Hukuk Cemiyeti reislerine birer telgraf gönderdi. ${ }^{66}$ Sözü edilen tarihte Teke (Antalya) Müdafaa-ı Hukuk Riyaseti'ne çekilen diğerleri ile aynı olan telgrafında;

"Livanızın yüksek rüşdü siyasi ve kabiliyeti vatanperveranesini irad eden netice-i intihaptan dolayı felaketi vatanı saadete tahvil gayesiyle senelerce evvel faaliyete başlamış olan Anadolu ve Rumeli Müdafaa-ı Hukuk Cemiyeti namına bütün liva halkını tebrik ederim. Memleketin bundan böyle naili füyuzat olması için livanızın aynı derecede yüksek hassasiyeti vatanperverane ile Cemiyet ve Fırkamıza zahir olacağından şüphem yoktur. Cenabı hak cümlenizi muvaffakı bilhayr eylesin.

Iş bu maruzatımın bilumum Müdafaa-ı Hukuk Teşkilatı ve Belediye heyetleriyle ahali-i muhteremeye iblağını hassaten rica eylerim efendim" demekteydi ${ }^{67}$.

İkinci devre Mebus seçimi sırasında Antalya Mutasarrıfı olarak görev yapan Hilmi Bey (Uran) hatıralarında "...hayli gürültülü ve ihtilaflı geçen Antalya adaylarının tespiti işinde umumun arzusunu açıklarken..." Mustafa Kemal Paşa'nın kendisiyle samimi muhaberelerde bulunduğunu, bilhassa kendisine çok gerekli gördüğü Rasih Efendi'nin mutlaka adaylar arasına girmesi konusunda ona güvendiğini belirtmektedir. Hatta beklemediği halde seçimi müteakip terfi olarak vali olarak Adana'ya atanmasını da Paşa'nın bu güvenine bağlamaktadır. ${ }^{68}$ Bu arada Ankara'dan bildirilen 29 Temmuz tarihli telgrafa göre Kastamonu Valiliğine Kırşehir Mutasarrıfı Fatin, Adana Valiliğine Antalya Mutasarrıfı Hilmi Bey'ler tayin edilmiştir. ${ }^{69}$

62 Muhammet Güçlü, "Dr. Burhanettin (Onat) Bey'in Raporuna Göre Antalya'da 1930 Belediye Seçimleri”, Toplumsal Tarih, S. 65, Mayıs 1999, s. 22.

63 Ahmet Cemaleddin Saraçoğlu, Gazeteler, Gazeteciler ve Olaylar Etrafinda Mütareke Yıllarında İstanbul, Haz. İsmail Dervişoğlu, İstanbul, 2009, Kitabevi, s. 76, 537.

64 Yakup Kadri Karaosmanoğlu, a.g.e. , s. 24-25.

65 Işıl Çakan, a.g.e. , s. 93-97.

66 Atatürk'ün Tamim, Telgraf ve Beyannameleri, C. 4, Ankara, 1991, s. 546.

67 Mustafa Üstün, a.g.m. , s. 41-42; Aynı telgraf Haziran ayının ortalarında Konya'da yayınlanan Halk gazetesinde üçüncü sayfadan "Gazi Paşa Hazretleri Afyonluları tebrik ediyor" başlığı ile veriliyordu. İlaveten yandaki sütunda ise Müdafaa-i Hukuk Grubu namzetlerinin dokuz maddelik umdesi yayınlanıyordu. Halk, 15 Haziran 1339.

68 Hilmi Uran, a.g.e., s. 148.

69 Halk, 31 Temmuz 1339. Mustafa Hilmi (Uran) Bey'in Teke (Antalya) Müstakil Mutasarrıflığı görevinden sonra kısa hayat hikâyesi şöyledir: Mustafa Hilmi Bey, 22 Ağustos 1923-13 Eylül 1925 tarihleri arasında Adana Valiliği yapmıştrr. Bir süre Ankara'da İthalat ve İhracat Şirketi Umum Müdürlüğü görevini yürüttükten sonra 1926 yılı ilkbahar mevsiminde Cumhuriyet Halk Fırkası, Mıntıka Müfettişi olarak yeniden Adana'ya gelmiştir. Böylece idari hayattan siyasi hayata geçen M. Hilmi Bey, Türkiye Büyük Millet Meclisi'nin üçüncü seçim devresinde Adana'dan mebus seçildi. Bu sırada parti müfettişliği görevini de muhafaza etmiştir. 1930 yılı Aralık ayı sonunda İsmet Paşa kabinesinde Nafia Vekili oldu. Bu görevinden sağlık sebebiyle 26 Ekim 1933 tarihinde istifa etti. Beş ay 
Hilmi Bey'in Antalya ile ilgisi konusunda son olarak Antalya Valiliği'ne hediye edilen otomobil konusundan söz edilebilir. Hilmi Bey, Adana Valiliği'ni görevini yaparken halefi Sabri (Öney) Bey'in valiliği sırasında şehrin ileri gelen tüccarlarından Moris adlı birisi vilayete Ford marka bir otomobil hediye etmiştir. Sabri Bey bir yandan otomobili kullanırken öbür yandan Dahiliye Vekaleti'ni bu bağıştan haberdar etmiştir. Dönemin Dahiliye Vekili Ferit (Tek) Bey Ankara'da bile az bulunan otomobilin (ki vilayetlere otomobil tahsisi yok) derhal Ankara'ya gönderilmesini istemiştir. Ama o dönemde yollar müsait olmadığı için karadan gönderilemeyen otomobil, ilk vapur ile Mersin'e gönderilmiştir. Hilmi Bey, Polis Müdürü Mansur Bey marifetiyle otomobili Adana'ya aldırmıştır. Bakanlığın “otomobili hemen Ankara'ya gönderiniz" yazısına cevaben 400 lira taşıma ücreti olduğunu bildirip tahsisat isteyen Hilmi Bey, para Adana Valiliği emrine gelene kadar dört beş ay otomobili kullandığını belirtir. ${ }^{70}$

\section{Sonuç}

1886 yılında Bodrum'da doğan Mustafa Hilmi Bey, Mülkiye-i Şahane'yi bitirdi. İdadi'yi bitirdiği İzmir'in Menemen ve Çeşme kazalarında kaymakamlık yaptı. Kars ve Trabzon'da Mülkiye Müfettişliği yaptıktan sonra 1920 yılında son Meclis-i Mebusan'a Muğla Mebusu olarak katıldı. Bir ara Milas'ta serbest ticaret yaptı ise de sonra yeniden memuriyete dönmek durumunda kaldı.

Ekim 1921-Temmuz 1923 tarihleri arasında Teke Müstakil Mutasarrıfı olarak görev yaptı. Bu görevi sırasında Büyük Taarruz' un hazırlığı ve icrasını yaşadı. Hilmi Bey'in yönettiği şehrin Ankara'nın iki kapısından birisi (diğeri önce Mudanya sonra İnebolu) olduğu göz önüne alınırsa yükü ve sorumluluğu anlaşılabilir. Ayrıca limanından dolayı Batı cephesinin asker, silah ve mühimmat açısından ikmali yanında Antalya şehrinin sorunlarıyla da uğraşmıştır. Bunların başında içme suyu sorunu ile sağlık işleri gelmekteydi. İçme suyu sorununu çözmeye görev süresi yetmediyse de sağılık işleri ile bir hayli cebelleşti. Örneğin Gureba Hastanesini elden geçirdi. Antalya'da Büyük Taarruz sonrası yaşanan Rum muhaceretini yönetti. Bu konuyu Çeşme Kaymakamlığı sırasındaki tecrübesine dayanarak bir hafta gibi sürede halletmeyi başardı. Bu arada Antalya-Alanya yolunun Serik kısmındaki köprü ve menfezlerin yapımına önemli katkı sağladı.

Hilmi Bey'in Teke Mutasarrıflığı'nın son döneminde ikinci dönem Mebus seçimi yapıldı.

boyunca Fransa'da bir sanatoryumda tedavi edildikten sonra 1934 yılı Nisan ayında ülkeye döndü. TBMM'nin IV, V, VI, VII ve VIII. seçim devrelerinde Seyhan'dan mebus seçildi. 1935 yılı yaz başlarında Cumhuriyet Halk Partisi İstanbul parti başkanlığına tayin edildi. Bu görevi Umumi Katiplik makamının Dahiliye Vekili'ne, vilayet parti reisliğinin valilere devredilmesine kadar sürdü. 24 Mart 1937-11 Kasım 1938 tarihleri arasında üç defa TBMM Reis Vekilliği görevini ifa etti. Mustafa Kemal Paşa'nın vefatından sonra 11 Kasım 1938 tarihinde kurulan Celal Bayar kabinesine Adliye Vekili olarak katıldı. 3 Ocak 1939 tarihinde Cumhuriyet Halk Partisi grubu tarafindan Meclis Grup Başkan Vekilliği'ne seçildiği için Adliye Vekilliği görevinden istifa etti. Meclis Grup Başkan Vekilliği görevi 19 Mayıs 1943 tarihine kadar sürdü. Şükrü Saraçoğlu kabinesinde 20 Mayıs 1943-5 Ağustos 1946 tarihleri arasında Dahiliye Vekili olarak bulundu. Bir ara Cumhuriyet Halk Partisi Grup Başkan Vekilliği görevine tayin edildiyse de 1946 yılı Ekim ayı sonlarında Genel Sekreterlik makamına getirildi. 17 Kasım 1947 tarihinde toplanan Cumhuriyet Halk Partisi'nin yedinci kurultayında genel başkan vekili seçildi. Bu görevi 1950 seçimlerinden sonra genel başkan vekilliği makamı lağvedilene kadar sürdü. 1950 seçimlerinde mebus seçilemeyen Hilmi Uran'ın siyasi hayat böylece noktalanmış oldu. Emekli olarak İstanbul'da yaşarken 21-22 Ekim 1957 tarihinde Pazartesi gecesi yaşadığı kalp krizi sonunda vefat etmiştir. Naşı Zincirlikuyu'daki Asri Mezarlığa defnedilmiştir. Sicil kaydına göre Fransızca ve Rumca bilen Hilmi Uran'ın bir kız, bir erkek evladı bulunmaktadır. Hilmi Uran, a.g.e. , s. 5-7; Mücellidoğlu Ali Çankaya, a.g.e. , s. 1174-1175.

70 Hilmi Uran, a.g.e., s. 168; Burada geçen Ford marka otomobil Emin Akif Ersoy'un belirttiği otomobil olabilir. Milli şairimiz Mehmet Akif Ersoy’un oğlu Emin Akif Ersoy, Milli Mücadele dönemine ilişkin hattralarında I. İnönü savaşından önce babasının Mebus seçildiği Burdur'a gittiklerini, oradan Antalya'ya geçerek onbeş gün kaldıklarını, dönüş yolculuğunu Dinar’a kadar adını belirtmediği Manavgatlı zengin bir tüccarın Ford marka otomobil ile yaptıklarını belirtir. Ayrıca Ankara'ya gelişlerinden sonra I. İnönü başarısının müjdesini aldıklarını ilave eder. Emin Akif Ersoy, Babam Mehmet Akif-Istiklal Harbi Hatıraları, Derleme-Giriş: Yusuf Turan Günaydın, İstanbul, 2016, s. 58. 
Olaylı geçen Antalya seçimlerini Mustafa Kemal Paşa'nın isteği doğrultusunda başarıyla sonuçlandırdı. Özellikle Rasih Hoca'nın seçilmesi Mustafa Kemal Paşa'yı memnun etmiş olacak ki seçimi müteakip terfi olarak Adana Valiliği'ne nakledildi. Bu çalışma ile Milli Mücadele'nin zor günlerinde, Sakarya Savaşı sonrasında, Büyük Taarruz sırasında ve Cumhuriyet öncesi dönemde Teke Mutasarrıflığı görevini yapmış olan Mustafa Hilmi Bey'in Antalya'daki faaliyetleri gün yüzüne çıkarıldı. Teke Mutasarrıfları arasında Antalya'da iz bırakan bir sima olan Hilmi Bey, sonraki yaşamında ülke çapında adını duyurmuş bir bürokrat ve siyasi olmuştur.

\section{KAYNAKÇA}

\section{A- Arşivler}

Başbakanlık Cumhuriyet Arşivi, 030.18.01.01.1.3.20.

B- Basın

Ağam Mizah Mecmuası, C. 1, S. 1, Ocak 1948.

Antalya'da Anadolu, 15 Eylül 1337.

Antalya'da Anadolu, 7 Mart 1338.

Antalya'da Anadolu, 5 Nisan 1338.

Antalya'da Anadolu, 8 Nisan 1338.

Antalya'da Anadolu, 12 Eylül 1338.

Hakimiyet-i Milliye, 10 Mayıs 1338.

Halk, 15 Haziran 1339.

Halk, 17 Haziran 1339.

Halk, 31 Temmuz 1339.

\section{C- Araştırma Eserler}

ARABACl, Caner, AYHAN, Bünyamin, DEMiRSOY, Adem, AYDI, Hakan (2009), Konya Basın Tarihi, Konya, 2. bs. , Palet Yayınevi.

Atatürk'ün Tamim, Telgraf ve Beyannameleri, C. 4, Ankara, 1991, Atatürk Araştırma Merkezi yayını.

BORATAV, Korkut (1982), Türkiye'de Devletçilik, Ankara, 2. bs. , Savaş Yayınevi.

ÇAKAN, Işı (1999), Türk Parlamento Tarihinde II. Meclis, İstanbul.

ÇANKAYA, Mücellidoğlu Ali (1968-1969), Yeni Mülkiye Tarihi ve Mülkiyeliler, C. 3, Ankara.

ÇARIKLI, Turgut (2005), Babam Hacim Muhittin Çarıklı-Bir Kuvay-ı Milliyecinin Yaşam Öyküsü, Yay. Haz. Y. Hakan Erdem, İstanbul.

DAYAR, Evren (bty.), Antalya Belediye Tarihi 1868-1923, Antalya, Antalya Büyükşehir Belediyesi Yayınları.

ERSOY, Emin Akif (2016), Babam Mehmet Akif-istiklal Harbi Hatıraları, Derleme-Giriş: Yusuf Turan Günaydın, İstanbul.

GAULis, Berthe Georges (1981), Kurtuluş Savaşı Sırasında Türk Milliyetçiliği, Çev. Cenap Yazansoy, İstanbul.

ERTEN, Süleyman Fikri (1996), Milli Mücadelede Antalya, Antalya.

GÜÇLÜ, Muhammet (1997), XX. Yüzyılın İlk Yarısında Antalya, Antalya.

GÜÇLÜ, Muhammet (1999), “Dr. Burhanettin (Onat) Bey'in Raporuna Göre Antalya'da 1930 Belediye Seçimleri", Toplumsal Tarih, S. 65, Mayıs 1999, s. 19-23.

GÜÇLÜ, Muhammet (2004), Dr. H. Burhanettin Onat ve Hayatı (1894-1976), Antalya.

GÜÇLÜ, Muhammet (2014), “Milli Mücadele Döneminde Hollandalı Gazeteci George Nypels'in Anadolu İzlenimleri (Aralık 1920-Mart 1921)" , Cumhuriyet Tarihi Araştırmaları Dergisi, S. 19, Bahar 2014, s. 119-145. 
Bodrumlu Mustafa Hilmi (Uran) Bey'in Teke (Antalya) Müstakil Mutasarrıflığı (29 Ekim 1921-22 Temmuz 1923)

GÜÇLÜ, Muhammet (2018), “Antalya Darülmuallimin-i İptidaiye (1903-1923)”, Selçukludan Cumhuriyet'e Sosyal Bilimlerde Antalya I, Ed. Bedia Koçakoğolu-Bahset Karslı vd. , Antalya, 2018, s. 282-302.

Mülazım Mustafa Hulusi (2006), Bir Kalpaklının Milli Mücadele Günlügü, Yay. haz. Bayram Kodaman-Fahrettin Tızlak, Isparta.

KANDENIR, Feridun (1966), "Ondokuzuncu Yüzyıl Sonlarında: İzmir", Tarih Konuşuyor, S. 29, Haziran 1966, s. 2414-2416.

KANSU, Mazhar Müfit, Erzurum'dan Ölümüne Kadar Atatürk'le Beraber, C. II, Ankara, 1998, 3. bs. , TTK Basımevi.

KANSU, Samih Nafiz (1964), iki Devrin Perde Arkası, İstanbul.

KARAOSMANOĞLU, Yakup Kadri (1968), Politikada 45 Yıl, Ankara.

NECATiGiL, Behçet (1980), Edebiyatımızda İsimler Sözlüğü, 10. bs. , İstanbul.

ONAT, Burhanettin (2000), Bir Zamanlar Antalya-Bir Antalya Sevdalısının Kaleminden, İstanbul.

ORAN, Nebahat (1997), Antalya Milletvekili Rasih (Kaplan) Bey'in I. ve II. Dönem Türkiye Büyük Millet Meclisi'ndeki Siyasi Faaliyetleri, Atatürk Üniversitesi Sosyal Bilimler Enstitüsü Tarih Anabilim Dalı Yayınlanmamış Yüksek Lisans Tezi, Erzurum.

ÖZ, Tabakoğlu Süleyman Nuri (1971), Bu Nasıl Adam? Bir Öğretmenin Anıları, İstanbul. ÖZTÜRK, Kazım (1995), Türk Parlamento Tarihi TBMM. II. Dönem 1923-1927, C. 3, Ankara. SARAÇOĞLU, Ahmet Cemaleddin (2009), Gazeteler, Gazeteciler ve Olaylar Etrafında Mütareke Yıllarında İstanbul, Haz. İsmail Dervişoğlu, İstanbul, Kitabevi.

SARISÖZEN, Güner (Haz.), Demokrat Parti Milletvekilleri Albümü 1946-1960, Demokratlar Kulübü Yayınları No. 17, Ankara, 1998.

SELEKLER, Macit (1960), Yarımasrın Arkasından-Antalya'da Kemer Melli-ibradı Serik, İstanbul.

SÜRGEViL, Sabri (2008), “Hilmi Uran (1886-1957)” , Osmanlılardan Günümüze Her Yönüyle Uluslararası Bodrum Sempozyumu (24-26 Ekim 2007)-Bildiriler, Haz. Ahmet Özgiray-M. Akif Erdoğru, Bodrum, s. 705-722.

URAN, Hilmi (2008), Meşrutiyet, Tek Parti, Çok Parti Hatıralarım (1908-1950), İstanbul, Yayına Hazırlayan: Cem Çobanlı-Pınar Güven.

ÜSTÜN, Mustafa (2004), “Antalya Tarihinden İzler”, Atso Vizyon, S. 197, Haziran 2004, s. 30-35.

ÜSTÜN, Mustafa (2004) “Antalya Tarihinden İzler”, Atso Vizyon, S. 198, Temmuz 2004, s. 38-42.

YUNUS NADi (1955), Ankara'nın ilk Günleri, İstanbul, Sel Yayınları.

YUNUS NADi (1955), Birinci Büyük Millet Meclisi'nin Açılışı ve İsyanlar, İstanbul, Sel Yayınları.

\section{D- Dijital Kaynaklar}

www.levantineheritage.com/adalia.htm (Erişim Tarihi: 15. 01. 2016) 


\section{RESIMLER}

Resim 1: Mustafa Hilmi (Uran) Bey (1886-1957) (Mücellidoğlu Ali Çankaya, a.g.e. , s. 1174.)

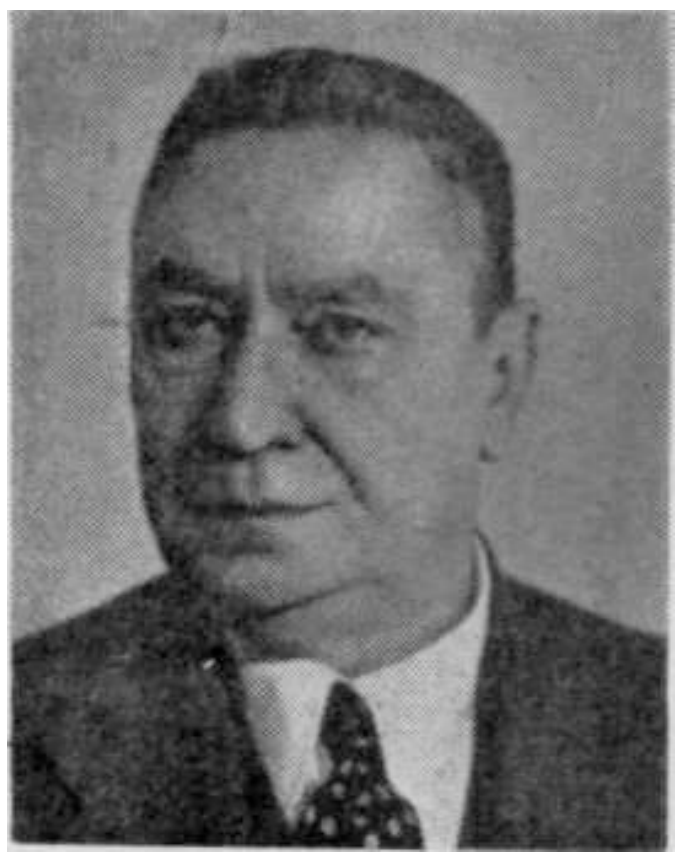

Resim 2: Antalya İskelesi (www.levantineheritage.com/adalia.htm, Erişim Tarihi: 15. 01. 2016)

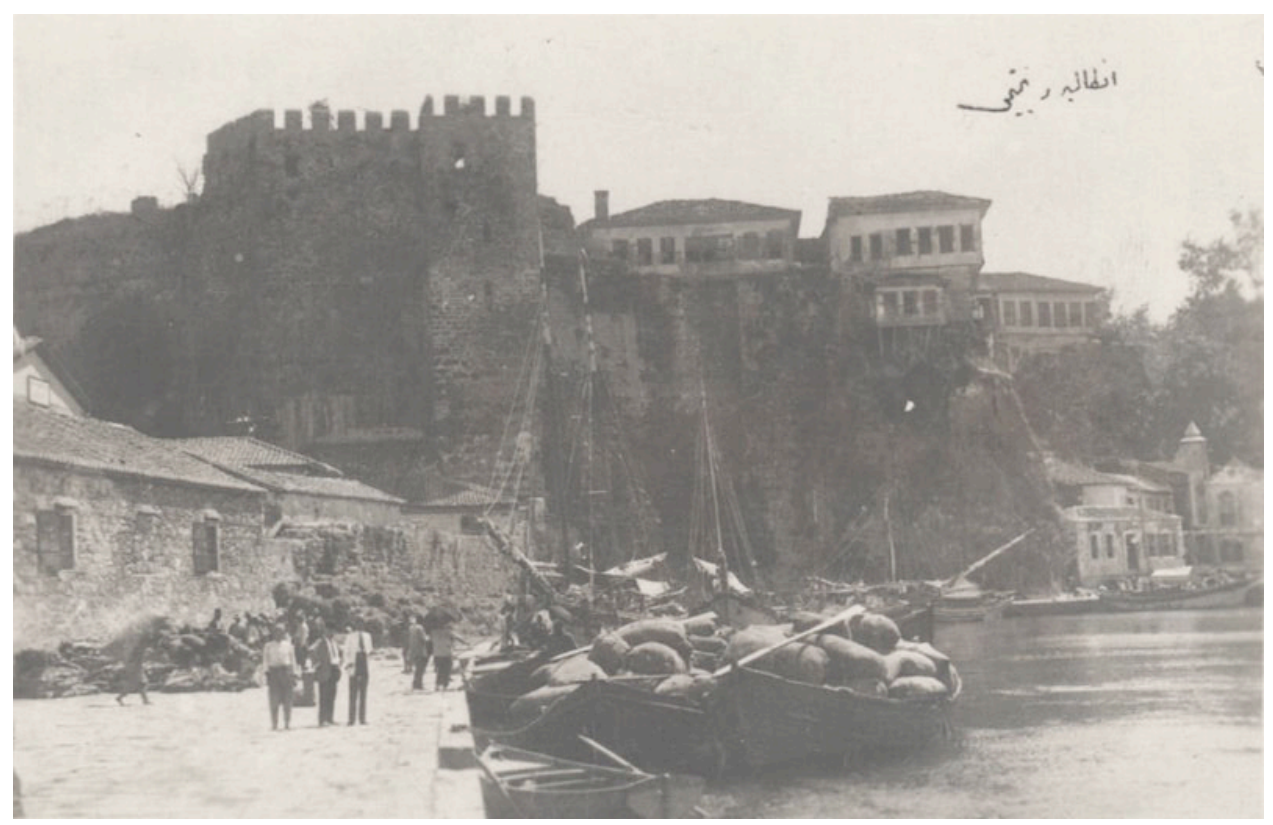


Bodrumlu Mustafa Hilmi (Uran) Bey'in Teke (Antalya) Müstakil Mutasarrıflığı (29 Ekim 1921-22 Temmuz 1923)

Resim 3: Antalya'da Rum Muhacereti (www.levantineheritage.com/adalia.htm, Erişim Tarihi: 15. 01. 2016)

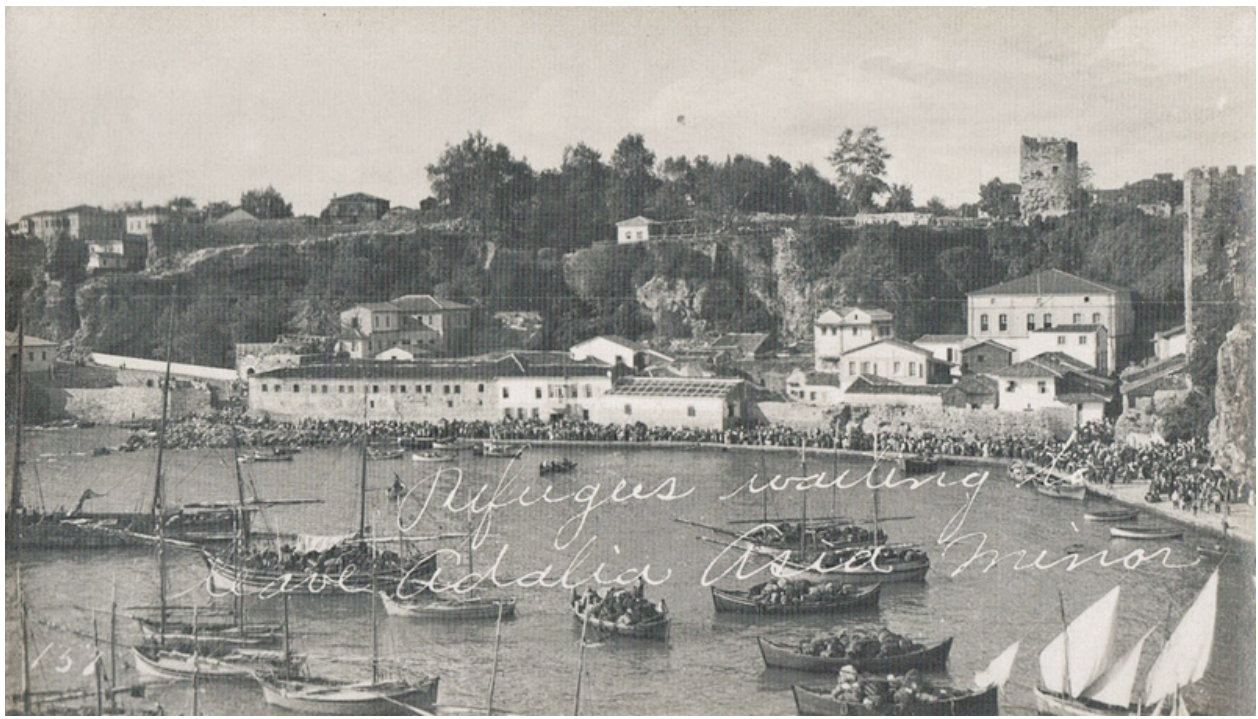

Resim 4: Antalya'da Rum Muhacereti (www.levantineheritage.com/adalia.htm, Erişim Tarihi: 15. 01. 2016)

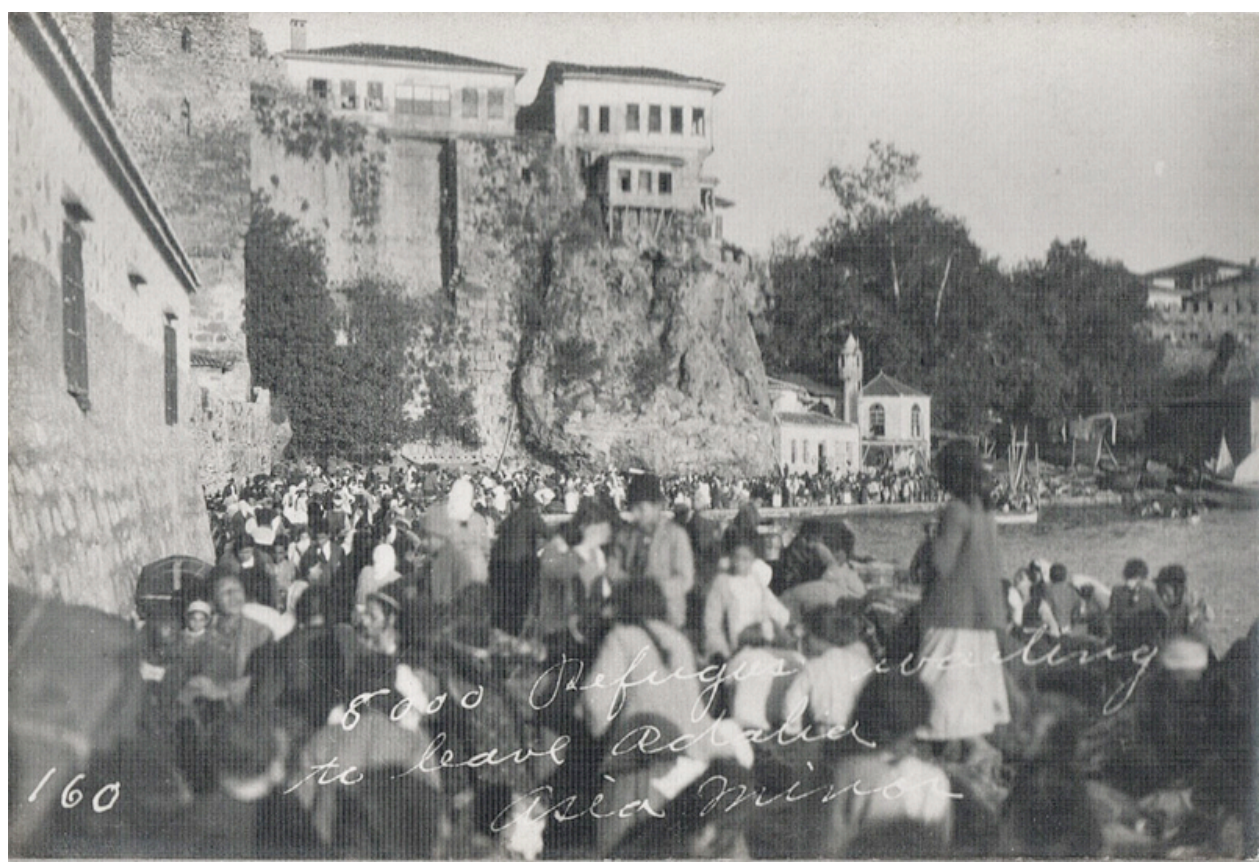


BE L G Sayı 18 (Yaz 2019/II) 19 Mayıs 1919'da Mustafa Kemal

M. Güçlü

Atatürk'ün Samsun'a Çıkışının 100. Yılı Anısına

Resim 5: Antalya'da Rum Muhacereti (www.levantineheritage.com/adalia.htm,Erişim

Tarihi: 15. 01. 2016)

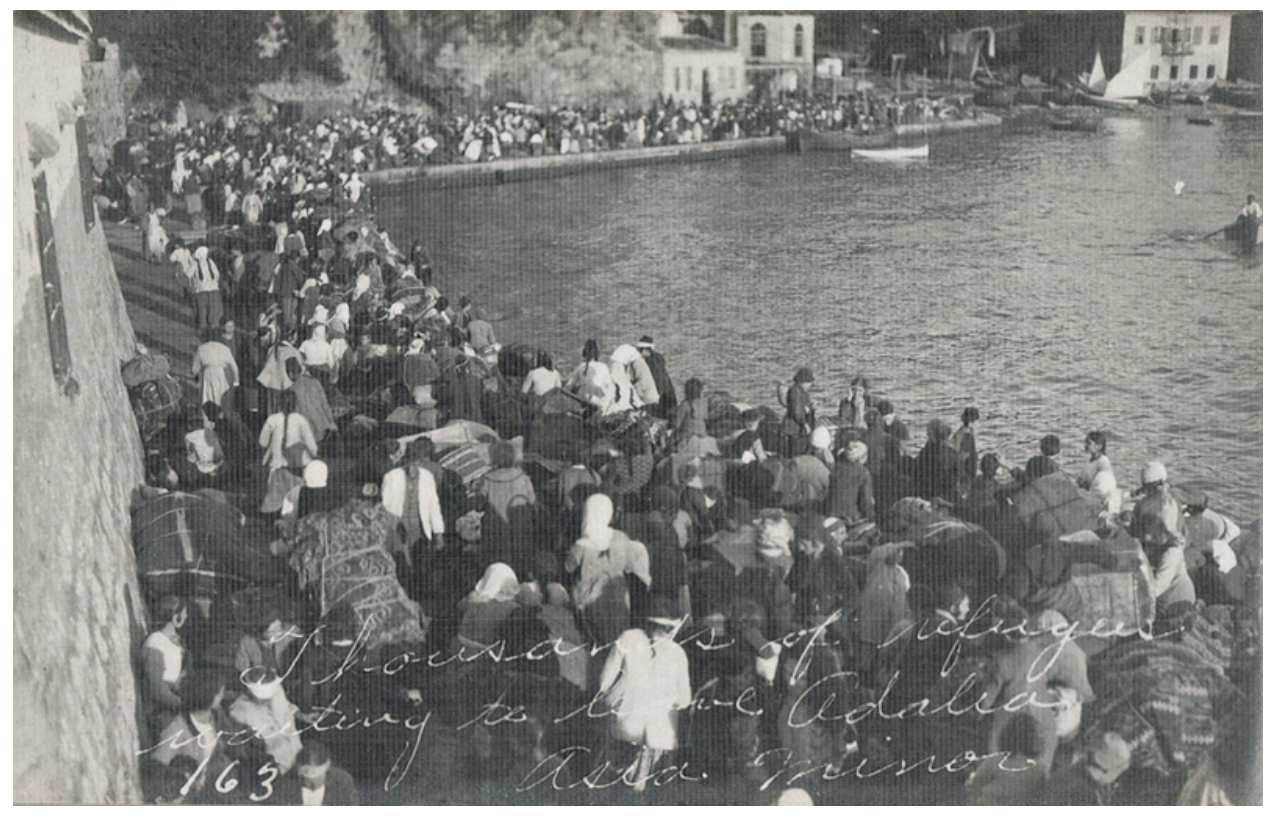

